Western University

Scholarship@Western

Chemistry Publications

Chemistry Department

Winter 11-30-2015

\title{
Side-Chain Boron Difluoride Formazanate Polymers via Ring-Opening Metathesis Polymerization
}

Samantha Novoa

Joseph A. Paquette

Stephanie M. Barbon

Ryan R. Maar

Joe Gilroy

jgilroy5@uwo.ca

Follow this and additional works at: https://ir.lib.uwo.ca/chempub

Part of the Chemistry Commons

Citation of this paper:

Novoa, Samantha; Paquette, Joseph A.; Barbon, Stephanie M.; Maar, Ryan R.; and Gilroy, Joe, "Side-Chain Boron Difluoride Formazanate Polymers via Ring-Opening Metathesis Polymerization" (2015). Chemistry Publications. 73.

https://ir.lib.uwo.ca/chempub/73 


\title{
Journal of Materials Chemistry C
}

\section{ARTICLE}

\section{Side-Chain Boron Difluoride Formazanate Polymers via Ring- Opening Metathesis Polymerization}

Received 00th January 20xx, Accepted 00th January 20xx

DOI: $10.1039 / x 0 x \times 00000 x$

www.rsc.org/

\begin{abstract}
Samantha Novoa, Joseph A. Paquette, Stephanie M. Barbon, Ryan R. Maar and Joe B. Gilroy*
\end{abstract}

\begin{abstract}
The synthesis, characterization, and ring-opening methathesis polymerization (ROMP) of a novel norbornene-based boron difluoride $\left(\mathrm{BF}_{2}\right)$ formazante monomer are described in detail. The polymerization studies confirmed ROMP to occur in the presence of $\mathrm{BF}_{2}$ formazanates, and also demonstrated the controlled nature of the polymerization. The polymers retained many of the unique characteristics of the monomers in dichloromethane, including absorption and emission at maximum wavelengths of 518 and $645 \mathrm{~nm}$, large Stoke's shifts (UST $=127 \mathrm{~nm}, 3,800 \mathrm{~cm}^{-1}$ ), and the ability to act as electron reservoirs to form borataverdazyl-based poly(radical anions) ( $\left.E_{\text {red1 }}^{\circ}=-0.95 \mathrm{~V}\right)$. Furthermore, the results described in this paper demonstrate the potential of these and related polymers based on $\mathrm{BF}_{2}$ formazanates as redox-active, light-harvesting materials.
\end{abstract}

\section{Introduction}

The incorporation of main-group elements into $\pi$-conjugated materials has proved to be an efficient strategy for the modification of their charge carrier mobility, spectroscopic characteristics, and redox activity. ${ }^{1}$ Main-chain $^{2}($ e.g., 1, 2) and side-chain $^{3}$ (e.g., $\left.\mathbf{3}, 4\right)$ polymers incorporating boron are an intriguing class of polymers, although their development has been relatively slow compared to those based on other main group elements (e.g., $\mathrm{S}, \mathrm{Si}$, and $\mathrm{P}){ }^{4}$<smiles>CC(C)(C)c1ccc2c(c1)B([Al])c1cc(C(C)(C)C)ccc1-2</smiles>

1

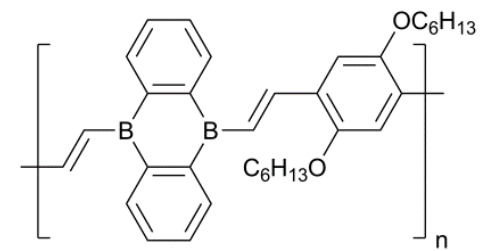

2

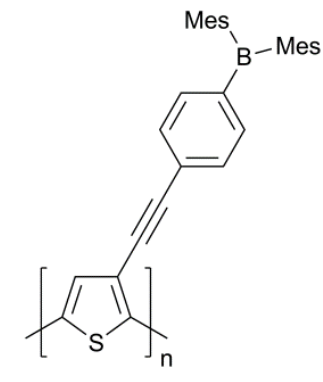

3

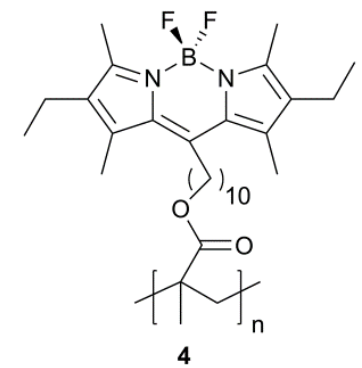

Department of Chemistry and the Centre for Advanced Materials and Biomaterials Research (CAMBR), The University of Western Ontario, London, Ontario, Canada, N6A $5 B 7$.

Electronic Supplementary Information (ESI) available: [NMR spectra, TGA and DSC data, and addition cyclic voltammograms]. See DOI: 10.1039/x0xx00000x
Formazanate ligands $5,{ }^{5,6}$ derived from formazans $6{ }^{7}$ are nitrogen-rich analogs of $\beta$-diketiminates $7 .^{8} \mathrm{BF}_{2}$ formazanate complexes have previously been shown to act as electron acceptors $^{5 b}$ and their spectroscopic properties have been tuned through variation of the degree of $\pi$-conjugation ${ }^{5 e}$ and the donor/acceptor properties of their nitrogen- and carbonbound substituents. ${ }^{5 c, 5 d}$ More recently, this promising class of functional molecular materials has been exploited as contrast agents for the fluorescence imaging of the cytoplasm of mouse fibroblast cells, ${ }^{5 h}$ as efficient electrochemiluminescent (ECL) emitters, ${ }^{9}$ and as precursors to unusual $\mathrm{B}(\mathrm{I})$-carbenoid intermediates. ${ }^{5 \mathrm{~g}}$

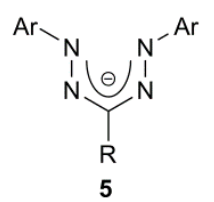<smiles>[R]C(N=[W])=NN[Te]</smiles><smiles>[R]C(N=[V])=N[Al]</smiles>

While rapid progress has been made in the development of molecular $\mathrm{BF}_{2}$ formazanates, they have not been incorporated into polymer scaffolds. The realization of polymerization methods tolerant to $\mathrm{BF}_{2}$ formazanates would allow for their unique properties to be combined with the processability of polymers. Herein, we describe the synthesis and characterization of a norbornene-containing $\mathrm{BF}_{2}$ formazanate monomer and explore its ring-opening metathesis polymerization (ROMP) behaviour with a view of developing a class of redox-active macromolecules that may ultimately show utility as light-harvesting materials. 


\section{Experimental section}

\section{General considerations}

Unless otherwise stated, all reactions were carried out under a nitrogen atmosphere using standard Schlenk techniques. Solvents were obtained from Caledon Laboratories, dried using an Innovative Technologies Inc. solvent purification system, collected under vacuum, and stored under a nitrogen atmosphere over $4 \AA$ molecular sieves. All other reagents were purchased from Sigma Aldrich or Alfa Aesar and used as received. 4-(bicyclo[2.2.1]hept-5-en-2-yl)benzaldehyde was synthesized using a published procedure. ${ }^{10} \mathrm{NMR}$ spectra were recorded on $400 \mathrm{MHz}\left({ }^{1} \mathrm{H}: 399.8 \mathrm{MHz},{ }^{11} \mathrm{~B}: 128.3 \mathrm{MHz},{ }^{19} \mathrm{~F}\right.$ : $376.1 \mathrm{MHz})$ of $600 \mathrm{MHz}\left({ }^{13} \mathrm{C}\right.$ : $\left.150.7 \mathrm{MHz}\right)$ Varian INOVA spectrometers. Spectra were referenced to residual $\mathrm{CHCl}_{3} 7.27$ ppm ( $\left({ }^{1} \mathrm{H} \mathrm{NMR}\right)$, and $\mathrm{CDCl}_{3}$ at $77.0 \mathrm{ppm}\left({ }^{13} \mathrm{C} \mathrm{NMR}\right) .{ }^{11} \mathrm{~B}$ spectra were referenced internally to $\mathrm{BF}_{3} \cdot \mathrm{OEt}_{2}$ at $0 \mathrm{ppm} .{ }^{19} \mathrm{~F}$ spectra were referenced internally to $\mathrm{CFCl}_{3}$ at $0 \mathrm{ppm}$. Mass spectra were recorded in positive-ion mode using a Finnigan MAT 8200 spectrometer. Infrared spectra were recorded using a Bruker Vector33 spectrometer.

\section{Absorption and Emission Spectroscopy}

Solution phase UV-Vis absorption spectra were recorded using a Cary 300 Scan instrument using standard quartz cells $(1 \mathrm{~cm}$ path length) with a scan range of 250 to $800 \mathrm{~nm}$. Molar extinction coefficients were determined from the slope of a plot of absorbance against concentration using four solutions with known concentrations. Thin-film absorption spectra were recorded for films prepared by spin coating polymer $\mathbf{1 2}$ onto glass from a $25 \mathrm{mg} \mathrm{mL}^{-1}$ solution in chlorobenzene. Solution phase emission spectra were recorded using a QM-4 SE spectrofluorometer equipped with double excitation and emission monochromators from Photon Technology International ( $5 \mathrm{~nm}$ slit width, $0.5 \mathrm{~nm}$ step size). Excitation wavelengths were chosen based on absorption maxima from the respective UV-Vis absorption spectrum in the same solvent. Data were corrected for wavelength-dependent detector sensitivity (Fig. S1) and quantum yields were determined relative to ruthenium tris(bipyridine) hexafluorophosphate ${ }^{11}$ by methods described by Fery-Forgues and co-workers. ${ }^{12}$

\section{X-ray Crystallography}

Single crystals for X-ray diffraction studies of monomer $\mathbf{1 1}$ were grown by vapour diffusion of hexanes into a saturated $\mathrm{CH}_{2} \mathrm{Cl}_{2}$ solution. The sample was mounted on a MiTeGen polyimide micromount with a small amount of Paratone $\mathrm{N}$ oil. X-ray diffraction measurements were made on a Bruker Kappa Axis Apex 2 diffractometer at a temperature of $110 \mathrm{~K}$. The data collection strategy was a number of $\omega$ and $\phi$ scans which collected data over a range of angles, $2 \theta$. The frame integration was performed using SAINT. ${ }^{13}$ The resulting data was scaled and absorption corrected using a multi-scan averaging of symmetry equivalent data using SADABS. ${ }^{14}$ The structures were solved by dual space methodology using the
Table 1 X-ray diffraction data collection and refinement details for $\mathrm{BF}_{2}$ formazanate monomer 11.

\begin{tabular}{|c|c|}
\hline & 11 \\
\hline Formula & $\mathrm{C}_{26} \mathrm{H}_{23} \mathrm{BF}_{2} \mathrm{~N}_{4}$ \\
\hline Formula Weight $(\mathrm{g} / \mathrm{mol})$ & 440.29 \\
\hline Crystal Dimensions $(\mathrm{mm})$ & $0.363 \times 0.207 \times 0.118$ \\
\hline Crystal Colour and Habit & red plate \\
\hline Crystal System & monoclinic \\
\hline Space Group & P $22_{1} / n$ \\
\hline Temperature, $\mathrm{K}$ & 110 \\
\hline$a, \AA$ & $14.339(6)$ \\
\hline$b, \AA$ & $9.360(3)$ \\
\hline$c, \AA$ & $17.092(7)$ \\
\hline$\alpha$, & 90 \\
\hline$\beta,{ }^{\circ}$ & $108.095(15)$ \\
\hline$\gamma_{i}^{\circ}$ & 90 \\
\hline$V, \AA^{3}$ & $2180.5(14)$ \\
\hline Z & 4 \\
\hline$\rho(\mathrm{g} / \mathrm{cm})$ & 1.341 \\
\hline$\lambda, \AA,(\mathrm{MoK} \alpha)$ & 0.71073 \\
\hline$\mu,\left(\mathrm{cm}^{-1}\right)$ & 0.092 \\
\hline Diffractometer Type & Bruker Kappa Axis Apex2 \\
\hline $\mathrm{R}_{\text {merge }}$ & 0.0511 \\
\hline $\mathrm{R}_{1}$ & 0.0622 \\
\hline$\omega \mathrm{R}_{2}$ & 0.1425 \\
\hline $\mathrm{R}_{1}$ (all data) & 0.0985 \\
\hline$\omega \mathrm{R}_{2}$ (all data) & 0.1621 \\
\hline GOF & 1.036 \\
\hline
\end{tabular}

$\mathrm{R}_{1}=\Sigma\left(\left|\mathrm{F}_{\mathrm{o}}\right|-\left|\mathrm{F}_{\mathrm{c}}\right|\right) / \Sigma \mathrm{F}_{\mathrm{o}} ; \omega \mathrm{R}_{2}=\left[\Sigma\left(w\left(\mathrm{~F}_{\mathrm{o}}^{2}-\mathrm{F}_{\mathrm{c}}^{2}\right)^{2}\right) / \Sigma\left(\omega \mathrm{F}_{\mathrm{o}}{ }^{4}\right)\right]$
$\mathrm{GOF}=\left[\Sigma\left(\omega\left(\mathrm{F}_{\mathrm{o}}^{2}-\mathrm{F}_{\mathrm{c}}^{2}\right)^{2}\right) /(\text { No. of reflns. }- \text { No. of params. })\right]^{1 / 2}$

SHELXT program. ${ }^{15}$ All non-hydrogen atoms were obtained from the initial solution. The hydrogen atoms were introduced at idealized positions and were treated in a mixed fashion. The structural model was fit to the data using full matrix leastsquares based on $F^{2}$. The calculated structure factors included corrections for anomalous dispersion from the usual tabulation. The structure was refined using the SHELXL-2014 program from the SHELXTL program package. ${ }^{16}$ Graphic plots were produced using the Mercury crystallographic program suite. See Table 1 and CCDC 1426952 for X-ray diffraction data collection and refinement details.

\section{Cyclic Voltammetry (CV)}

$\mathrm{CV}$ experiments were performed with a Bioanalytical Systems Inc. (BASi) Epsilon potentiostat and analyzed using BASi Epsilon software. Typical electrochemical cells consisted of a threeelectrode setup including a glassy carbon working electrode, platinum counter electrode, and silver pseudo reference electrode. Experiments were run at variable scan rates in degassed, dry $\mathrm{CH}_{2} \mathrm{Cl}_{2}$ or THF solutions of the analyte (ca. 1 $\mathrm{mM}$ ) and electrolyte $\left(0.1 \mathrm{M} \mathrm{nBu}_{4} \mathrm{NPF}_{6}\right)$. Cyclic voltammograms were referenced relative to the ferrocene/ferrocenium redox couple (ca. $1 \mathrm{mM}$ internal standard) and corrected for internal cell resistance using the BASi Epsilon software.

\section{Gel Permeation Chromatography (GPC)}

GPC experiments were conducted in chromatography grade THF at concentrations of $5 \mathrm{mg} \mathrm{mL}^{-1}$ using a Viscotek GPCmax VE 2001 GPC instrument equipped with an Agilent PolyPore 
guard column (PL1113-1500) and two sequential Agilent PolyPore GPC columns packed with porous poly(styrene-codivinylbenzene) particles ( $\mathrm{MW}$ range 200-2,000,000 $\mathrm{g} \mathrm{mol}^{-1}$; PL1113-6500) regulated at a temperature of $30{ }^{\circ} \mathrm{C}$. Signal response was measured using a Viscotek VE 3580 RI detector, and molecular weights were determined by comparison of the maximum $\mathrm{RI}$ response with a calibration curve (10 points, 1,500-786,000 $\mathrm{g} \mathrm{mol}^{-1}$ ) established using 10 monodisperse polystyrene standards purchased from Viscotek.

\section{Thermal Analysis}

Thermal degradation studies were performed using a TA Instruments Q600 SDT TGA. A sample of polymer 12 was placed in an alumina cup and heated at a rate of $10{ }^{\circ} \mathrm{C} \mathrm{min}-1$ from room temperature to $800{ }^{\circ} \mathrm{C}$ under a flow of nitrogen $\left(100 \mathrm{~mL} \mathrm{~min}^{-1}\right)$. Glass transition temperatures were determined using Differential Scanning Calorimetry (DSC) on a TA Instruments DSC Q20. A sample of polymer $\mathbf{1 2}$ was placed in an aluminum Tzero pan and heated from $40{ }^{\circ} \mathrm{C}$ to $200{ }^{\circ} \mathrm{C}$ at $10{ }^{\circ} \mathrm{C} \mathrm{min}{ }^{-1}$ under a flow of nitrogen $\left(50 \mathrm{~mL} \mathrm{~min}^{-1}\right)$ and cooled down to $20{ }^{\circ} \mathrm{C}$ at $10{ }^{\circ} \mathrm{C} \mathrm{min}{ }^{-1}$, before the sample underwent another heating/cooling cycle. The glass transition was determined from the second heating/cooling cycle.

\section{Synthetic methods}

\section{Preparation of norbornene-substituted hydrazone 9}

In air, 4-(bicyclo[2.2.1] hept-5-en-2-yl)benzaldehyde 8 (1.50 g, $7.57 \mathrm{mmol}$ ) was dissolved in $\mathrm{EtOH}(10 \mathrm{~mL})$ before a drop of 12 $\mathrm{M} \mathrm{HCl}$ and phenyl hydrazine $(0.82 \mathrm{~g}, 0.75 \mathrm{~mL}, 7.6 \mathrm{mmol})$ were added. Almost immediately, an off-white precipitate was formed and the solution was heated to $80{ }^{\circ} \mathrm{C}$ and allowed to reflux for $30 \mathrm{~min}$. Upon cooling, the off-white precipitate was isolated by filtration and washed with cold ethanol $(2 \times 10 \mathrm{~mL})$ to afford hydrazone 9 . Yield $=1.77 \mathrm{~g}, 81 \%$. Hydrazone 9 was employed in subsequent reactions without further purification. ${ }^{1} \mathrm{H}$ NMR $\left(399.8 \mathrm{MHz}, \mathrm{CDCl}_{3}\right): \delta 7.69(\mathrm{~s}, 1 \mathrm{H}, \mathrm{CH})$, 7.62-7.55 (m, 3H, aryl $\mathrm{CH}), 7.31-7.26(\mathrm{~m}, 3 \mathrm{H}, \operatorname{aryl} \mathrm{CH}), 7.12(\mathrm{~d}$ ${ }^{3} J_{\mathrm{HH}}=8 \mathrm{~Hz}, 2 \mathrm{H}$, aryl $\left.\mathrm{CH}\right), 6.88\left(\mathrm{t},{ }^{3} \mathrm{~J}_{\mathrm{HH}}=7 \mathrm{~Hz}, 1 \mathrm{H}\right.$, aryl $\left.\mathrm{CH}\right)$, 6.29-6.25 (m, $1 \mathrm{H},=\mathrm{CH}), 6.21-6.16(\mathrm{~m}, 1 \mathrm{H},=\mathrm{CH}), 2.99(\mathrm{br} \mathrm{s}, 1 \mathrm{H}$, $\mathrm{CH}), 2.92(\mathrm{br} \mathrm{s}, 1 \mathrm{H}, \mathrm{CH}), 2.77-2.71(\mathrm{~m}, 1 \mathrm{H}, \mathrm{CH}), 1.79-1.72(\mathrm{~m}$, $\left.1 \mathrm{H}, \mathrm{CH}_{2}\right), 1.70-1.62\left(\mathrm{~m}, 1 \mathrm{H}, \mathrm{CH}_{2}\right), 1.59\left(\mathrm{~d},{ }^{3} \mathrm{JHH}_{\mathrm{HH}}=8 \mathrm{~Hz}, 1 \mathrm{H}, \mathrm{CH}_{2}\right)$, $1.48-1.43\left(\mathrm{~m}, 1 \mathrm{H}, \mathrm{CH}_{2}\right)$.

\section{Preparation of norbornene-substituted formazan 10}

In air, $\mathrm{Na}_{2} \mathrm{CO}_{3}(2.19 \mathrm{~g}, 20.6 \mathrm{mmol})$ and $n \mathrm{Bu}_{4} \mathrm{NBr}(0.21 \mathrm{~g}, 10 \mathrm{~mol}$ \%) were mixed with $\mathrm{CH}_{2} \mathrm{Cl}_{2}(60 \mathrm{~mL})$ and deionized $\mathrm{H}_{2} \mathrm{O}(60 \mathrm{~mL})$ and the solution was left to stir in an ice bath for $15 \mathrm{~min}$. Meanwhile, in a separate flask, aniline $(0.60 \mathrm{~g}, 0.59 \mathrm{~mL}, 6.4$ mmol) was mixed with $12 \mathrm{M} \mathrm{HCl}(1.6 \mathrm{~mL}, 19 \mathrm{mmol})$ in deionized $\mathrm{H}_{2} \mathrm{O}(1.6 \mathrm{~mL})$. This solution was cooled in an ice bath for $15 \mathrm{~min}$ before a cooled solution of sodium nitrite $(0.51 \mathrm{~g}$, $7.4 \mathrm{mmol}$ ) in deionized $\mathrm{H}_{2} \mathrm{O}(5 \mathrm{~mL})$ was added dropwise. The resulting reaction mixture, which contained diazonium salt, was allowed to stir in an ice bath for an additional $10 \mathrm{~min}$. Hydrazone 9 ( $1.86 \mathrm{~g}, 6.46 \mathrm{mmol})$ was then added to the flask containing $\mathrm{CH}_{2} \mathrm{Cl}_{2} / \mathrm{H}_{2} \mathrm{O}$, and allowed to stir for $30 \mathrm{~s}$, before the diazonium-containing solution was added dropwise. The solution turned dark red after approximately $2 \mathrm{~min}$. The mixture was allowed to stir in an ice bath for an additional 60 min before the organic layer was collected and washed with deionized $\mathrm{H}_{2} \mathrm{O}\left(3 \times 50 \mathrm{~mL}\right.$ ), dried over $\mathrm{MgSO}_{4}$, gravity filtered, and concentrated in vacuo. The resulting dark-red oil was purified by flash chromatography $\left(\mathrm{CH}_{2} \mathrm{Cl}_{2}\right.$, neutral alumina) to yield norbornene-substituted formazan $\mathbf{1 0}$ as a dark-red microcrystalline solid that appeared gold in colour under intense lighting. Yield $=1.54 \mathrm{~g}, 61 \%$. M.p. $110-112{ }^{\circ} \mathrm{C}$. ${ }^{1} \mathrm{H}$ NMR $\left(400.1 \mathrm{MHz}, \mathrm{CDCl}_{3}\right): \delta 15.35$ (br s, $\left.1 \mathrm{H}, \mathrm{NH}\right), \delta 8.07\left(\mathrm{~d},{ }^{3} \mathrm{~J}_{\mathrm{HH}}=8\right.$ $\mathrm{Hz}, 2 \mathrm{H}$, aryl CH), $7.70\left(\mathrm{~d},{ }^{3} J_{\mathrm{HH}}=8 \mathrm{~Hz}, 4 \mathrm{H}\right.$, aryl CH), $7.47\left(\mathrm{t},{ }^{3} \mathrm{~J}_{\mathrm{HH}}=\right.$ $8 \mathrm{~Hz}, 4 \mathrm{H}$, aryl $\mathrm{CH}), 7.37\left(\mathrm{~d},{ }^{3} \mathrm{~J}_{\mathrm{HH}}=8 \mathrm{~Hz}, 2 \mathrm{H}\right.$, aryl CH), $7.30\left(\mathrm{~d},{ }^{3} J_{\mathrm{HH}}\right.$ $=7 \mathrm{~Hz}, 2 \mathrm{H}$, aryl $\mathrm{CH}), 6.32-6.28(\mathrm{~m}, 1 \mathrm{H},=\mathrm{CH}), 6.22-6.18(\mathrm{~m}, 1 \mathrm{H}$, $=\mathrm{CH}), 3.01(\mathrm{br} \mathrm{s}, 1 \mathrm{H}, \mathrm{CH}), 2.97(\mathrm{br} \mathrm{s}, 1 \mathrm{H}, \mathrm{CH}), 2.81-2.76(\mathrm{~m}, 1 \mathrm{H}$, $\mathrm{CH}), 1.84-1.78\left(\mathrm{~m}, 1 \mathrm{H}, \mathrm{CH}_{2}\right), 1.72-1.67\left(\mathrm{~m}, 1 \mathrm{H}, \mathrm{CH}_{2}\right), 1.65(\mathrm{~d}$, $\left.{ }^{3} J_{\mathrm{HH}}=9 \mathrm{~Hz}, 1 \mathrm{H}, \mathrm{CH}_{2}\right), 1.50-1.45\left(\mathrm{~m}, 1 \mathrm{H}, \mathrm{CH}_{2}\right) .{ }^{13} \mathrm{C}\left\{{ }^{1} \mathrm{H}\right\} \mathrm{NMR}$ $\left(150.7 \mathrm{MHz}, \mathrm{CDCl}_{3}\right): \delta 147.8,145.6,141.2,137.3,137.2,134.7$, 129.3, 127.6, 127.3, 125.8, 118.7, 48.3, 45.8, 43.5, 42.3, 33.6. FT-IR (KBr): 3,320 (w), 3,057 (m), 2,969 (s), 2,871 (w), 1,598 (s), 1,499 (s), 1,454 (s), 1,355 (m), 1,234 (s) cm ${ }^{-1}$. UV-Vis $\left(\mathrm{CH}_{2} \mathrm{Cl}_{2}\right)$ : $\lambda_{\max } 491 \mathrm{~nm}\left(\varepsilon=9,750 \mathrm{M}^{-1} \mathrm{~cm}^{-1}\right)$. Mass Spec. (El, +ve mode): exact mass calculated for $\mathrm{C}_{26} \mathrm{H}_{24} \mathrm{~N}_{4}$ : 392.2001; exact mass found: 392.1994; difference: $-1.8 \mathrm{ppm}$.

\section{Preparation of norbornene-substituted $\mathrm{BF}_{2}$ formazanate 11}

Norbornene-substituted formazan 10 (1.00 g, $2.55 \mathrm{mmol})$ was dissolved in $150 \mathrm{~mL}$ dry toluene. $\mathrm{NEt}_{3}(0.78 \mathrm{~g}, 1.1 \mathrm{~mL}, 7.7$ $\mathrm{mmol}$ ) was then added slowly, and the solution was allowed to stir for $10 \mathrm{~min}$. $\mathrm{BF}_{3} \cdot \mathrm{OEt}_{2}(1.8 \mathrm{~g}, 1.6 \mathrm{~mL}, 13 \mathrm{mmol})$ was then added, and the solution was heated to $80{ }^{\circ} \mathrm{C}$ and left to stir for $16 \mathrm{~h}$. During this time, the colour of the solution changed from dark red/purple to dark purple. After cooling to room temperature, deionized $\mathrm{H}_{2} \mathrm{O}(10 \mathrm{~mL})$ was added to quench any excess boron compounds. The toluene solution was then washed with deionized $\mathrm{H}_{2} \mathrm{O}(3 \times 25 \mathrm{~mL})$, dried over $\mathrm{MgSO}_{4}$, gravity filtered, and concentrated in vacuo. The resulting dark purple residue was purified by flash chromatography $\left(\mathrm{CH}_{2} \mathrm{Cl}_{2}\right.$, neutral alumina) and recrystallized from methanol to yield $\mathrm{BF}_{2}$ formazante monomer $\mathbf{1 1}$ as a dark-purple solid. Yield $=0.60 \mathrm{~g}$, 53\%. M.p. $145-147{ }^{\circ} \mathrm{C}$. ${ }^{1} \mathrm{H}$ NMR (399.8 MHz, CDCl 3 ): $\delta 8.05$ (d, $\left.{ }^{3} J_{\mathrm{HH}}=8 \mathrm{~Hz}, 2 \mathrm{H}, \operatorname{aryl} \mathrm{CH}\right), 7.92\left(\mathrm{~d},{ }^{3} \mathrm{~J}_{\mathrm{HH}}=8 \mathrm{~Hz}, 4 \mathrm{H}\right.$, aryl $\left.\mathrm{CH}\right), 7.52-$ $7.39(\mathrm{~m}, 8 \mathrm{H}$, aryl $\mathrm{CH}), 6.32-6.28(\mathrm{~m}, 1 \mathrm{H},=\mathrm{CH}), 6.23-6.19(\mathrm{~m}$, $1 \mathrm{H},=\mathrm{CH}), 3.02(\mathrm{br} \mathrm{s}, 1 \mathrm{H}, \mathrm{CH}), 2.97(\mathrm{br} \mathrm{s}, 1 \mathrm{H}, \mathrm{CH}), 2.83-2.77(\mathrm{~m}$, $1 \mathrm{H}, \mathrm{CH}), 1.84-1.77\left(\mathrm{~m}, 1 \mathrm{H}, \mathrm{CH}_{2}\right), 1.74-1.67\left(\mathrm{~m}, 1 \mathrm{H}, \mathrm{CH}_{2}\right), 1.63$ $\left(\mathrm{d},{ }^{3} \mathrm{~J}_{\mathrm{HH}}=9 \mathrm{~Hz}, 1 \mathrm{H}, \mathrm{CH}_{2}\right), 1.50-1.46\left(\mathrm{~m}, 1 \mathrm{H}, \mathrm{CH}_{2}\right) .{ }^{13} \mathrm{C}\left\{{ }^{1} \mathrm{H}\right\} \mathrm{NMR}$ $\left(150.7 \mathrm{MHz}, \mathrm{CDCl}_{3}\right)$ : $\delta 149.4,147.7,143.8,137.4,137.2,130.9$, 129.6, 129.0, 127.9, 125.4, 123.4, 48.3, 45.8, 43.7, 42.3, 33.7. ${ }^{11} \mathrm{~B}$ NMR $\left(128.3 \mathrm{MHz}, \mathrm{CDCl}_{3}\right): \delta-0.6\left(\mathrm{t},{ }^{1} \mathrm{~J}_{\mathrm{BF}}=29 \mathrm{~Hz}\right) .{ }^{19} \mathrm{~F} \mathrm{NMR}$ (376.1 MHz, CDCl 3 ): $\delta-145.1\left(\mathrm{q},{ }^{1}{ }_{\mathrm{FB}}=29 \mathrm{~Hz}\right)$. FT-IR $(\mathrm{KBr}): 3,064$ $(w), 2,961(m), 2,880(w), 1,589(w), 1,490(m), 1,462(m)$, $1,420(w), 1,356(\mathrm{~m}), 1,264$ (s) $\mathrm{cm}^{-1}$. UV-Vis $\left(\mathrm{CH}_{2} \mathrm{Cl}_{2}\right): \lambda_{\max } 518$ $\mathrm{nm}\left(\varepsilon=15,200 \mathrm{M}^{-1} \mathrm{~cm}^{-1}\right)$. Mass Spec. (El, +ve mode): exact mass calculated for $\mathrm{C}_{26} \mathrm{H}_{23} \mathrm{BF}_{2} \mathrm{~N}_{4}$ : 440.1984; exact mass found: 440.2004; difference: +4.5 ppm. 
Representative preparation of norbornene-substituted boron difluoride formazanate polymer 12

Norbornene-substituted boron difluoride formazanate monomer 11 (0.10 g, $0.23 \mathrm{mmol})$ was dissolved in degassed $\mathrm{CH}_{2} \mathrm{Cl}_{2}(9.9 \mathrm{~mL})$, and the solution was left to stir in an ice bath for $15 \mathrm{~min}$. Meanwhile, Grubbs' 3rd generation catalyst (Grubbs III) ( $\left.0.002 \mathrm{~g}, 2 \times 10^{-3} \mathrm{mmol}, 1 \mathrm{~mol} \%\right)$ was dissolved in degassed $\mathrm{CH}_{2} \mathrm{Cl}_{2}(0.1 \mathrm{~mL})$, and the solution was left in an ice bath for $15 \mathrm{~min}$. The catalyst solution was then added to the solution of $\mathbf{1 1}$ and the mixture allowed to stir in an ice bath for $5 \mathrm{~min}$. After $5 \mathrm{~min}$, ethyl vinyl ether $(0.409 \mathrm{~g}, 5.68 \mathrm{mmol}, 20$ equiv.) was added and the solution was allowed to stir for $10 \mathrm{~s}$ in an ice bath, and then allowed to reach room temperature while stirring under nitrogen for $30 \mathrm{~min}$. The resulting dark purple polymer was purified by flash chromatography $\left(\mathrm{CH}_{2} \mathrm{Cl}_{2}\right.$, neutral alumina) and precipitated from pentane. Norbornenesubstituted boron difluoride formazanate polymer $\mathbf{1 2}$ was isolated as a purple solid by centrifugation and dried at $40{ }^{\circ} \mathrm{C}$ in vacuo for $16 \mathrm{~h}$. Yield $=0.090 \mathrm{~g}, 90 \% .{ }^{1} \mathrm{H}$ NMR $(399.8 \mathrm{MHz}$, $\mathrm{CDCl}_{3}$ ) $\delta$ 8.20-7.55 (br m, 7H, aryl $\left.\mathrm{CH}\right), 7.55-6.80(\mathrm{br} \mathrm{m}, 7 \mathrm{H}$, aryl $\mathrm{CH}$ ), 5.23 (br s, $2 \mathrm{H},=\mathrm{CH}), 2.72(\mathrm{br} \mathrm{s}, 3 \mathrm{H}, \mathrm{CH}), 1.92(\mathrm{br} \mathrm{s}, 3 \mathrm{H}$, $\left.\mathrm{CH}_{2}\right), 1.30\left(\mathrm{br} \mathrm{s}, 1 \mathrm{H}, \mathrm{CH}_{2}\right.$, overlaps with residual pentane $\mathrm{CH}_{2}$ ). ${ }^{11} \mathrm{~B} N M R\left(128.3 \mathrm{MHz}, \mathrm{CDCl}_{3}\right): \delta-0.6\left(\mathrm{t},{ }^{1} J_{\mathrm{BF}}=28 \mathrm{~Hz}\right),-0.7\left(\mathrm{t},{ }^{1} J_{\mathrm{BF}}\right.$ $=29 \mathrm{~Hz}) \cdot{ }^{19} \mathrm{~F} \mathrm{NMR}\left(376.1 \mathrm{MHz}, \mathrm{CDCl}_{3}\right): \delta-145.1$ (br s),-143.2 ppm (br s). FT-IR (KBr): 3,074 (w), 2,998 (w), 2,945 (s), 2,871 (w), 1,589 (s), 1,490 (m), 1,462 (m), 1,431 (w), 1,358 (s), 1,298 (s) $\mathrm{cm}^{-1}$. UV-Vis $\left(\mathrm{CH}_{2} \mathrm{Cl}_{2}\right): \lambda_{\max }=518 \mathrm{~nm}\left(\varepsilon=14,350 \mathrm{M}^{-1} \mathrm{~cm}^{-1}\right)$. GPC (THF, conventional calibration vs. PS standards): $M_{n}=$ $35,900 \mathrm{~g} \mathrm{~mol}^{-1}, \mathrm{M}_{\mathrm{w}}=41,450 \mathrm{~g} \mathrm{~mol}^{-1}, Ð=1.15$.

\section{Kinetic studies for the ROMP of $\mathrm{BF}_{2}$ formazanate monomer 11}

\section{Monomer conversion as a function of time}

Norbornene-substituted $\mathrm{BF}_{2}$ formazanate monomer $\mathbf{1 1}(0.30 \mathrm{~g}$, $0.68 \mathrm{mmol}$ ) was dissolved in degassed $\mathrm{CH}_{2} \mathrm{Cl}_{2}(29.6 \mathrm{~mL})$ and the solution was left to stir in an ice bath for $20 \mathrm{~min}$. Meanwhile, Grubbs III (0.006 g, 1 mol\%) was dissolved in degassed $\mathrm{CH}_{2} \mathrm{Cl}_{2}$ $(0.4 \mathrm{~mL})$ and left to stir in an ice bath for $20 \mathrm{~min}$. The catalyst solution was then added rapidly in one portion to the solution of 11 and the mixture was allowed to stir in an ice bath. Aliquots of $c a .3 \mathrm{~mL}$ of this reaction were taken at $1 \mathrm{~min}$ intervals (1-8 $\mathrm{min})$, and added to separate flasks containing ethyl vinyl ether $(0.1 \mathrm{~mL}, 2 \mathrm{mmol}$, ca. 25 equiv.) in order to cease polymerization. Each aliquot solution was allowed to reach room temperature while stirring under nitrogen for 30 $\mathrm{min}$. All aliquots were then purified by flash chromatography $\left(\mathrm{CH}_{2} \mathrm{Cl}_{2}\right.$ neutral alumina) and analyzed without further purification. The conversion of monomer to polymer was calculated based on the comparison between the integration values determined by ${ }^{1} \mathrm{H}$ NMR spectroscopy for the vinyl groups of monomer 11 ( $\mathrm{m}, 6.32-6.28 \mathrm{ppm}$ and $\mathrm{m}, 6.23-6.19$ $\mathrm{ppm}$ ) and polymer 12 (br s, $5.23 \mathrm{ppm}$ ). A semilogarithmic plot was constructed based on the calculated degree of monomer conversions at different times.

\section{Molecular weight as a function of catalyst:monomer ratio} In five separate flasks, monomer $11(0.030 \mathrm{~g}, 0.068 \mathrm{mmol})$ was dissolved in degassed $\mathrm{CH}_{2} \mathrm{Cl}_{2}$ to yield a final reaction concentration of $10 \mathrm{mg} \mathrm{mL}^{-1}$; these solutions were left to stir in an ice bath for $20 \mathrm{~min}$. Meanwhile, Grubbs III (0.015 g, 0.17 mmol) was dissolved in degassed $\mathrm{CH}_{2} \mathrm{Cl}_{2}(2 \mathrm{~mL})$ and left to stir in an ice bath for $20 \mathrm{~min}$. Various amounts of the catalyst solution were then added to each solution of $\mathbf{1 1}$ in order to yield the following catalyst:monomer ratios: 1:100, 1:80, 1:60, $1: 40,1: 20$. After $5 \mathrm{~min}$, ethyl vinyl ether $(0.1 \mathrm{~mL}, 2 \mathrm{mmol}, \mathrm{ca}$. 25 equiv.) was added to cease polymerization, and the individual reactions were allowed to reach room temperature while stirring under nitrogen for $30 \mathrm{~min}$. The resulting polymers were then purified by flash chromatography $\left(\mathrm{CH}_{2} \mathrm{Cl}_{2}\right.$ neutral alumina) and analyzed without further purification. The degree of polymerization for each polymer studied was determined by GPC analysis in THF (conventional calibration vs. polystyrene).

\section{Results and discussion}

\section{Monomer Synthesis and Characterization}

The synthetic approach employed for monomer synthesis are shown in Scheme 1. Briefly, 4-(bicyclo[2.2.1]hept-5-en-2yl)benzaldehyde 8 was combined with phenylhydrazine to form hydrazone 9, which was isolated by filtration and used without further purification (Fig. S2). Hydrazone 9 was converted to norbornene-substituted formazan 10 under biphasic conditions, following the procedure originally developed by Katritzky and co-workers. ${ }^{17}$ It should be noted that hydrazone $\mathbf{9}$ and phenyldiazonium chloride must be added to the biphasic mixture in quick succession as prolonged stirring of hydrazone $\mathbf{9}$ in this mixture resulted in decomposition. The formation of formazan $\mathbf{1 0}$ was confirmed using ${ }^{1} \mathrm{H}$ NMR spectroscopy ( $\mathrm{NH}$ at $15.35 \mathrm{ppm}$ ) and UV-Vis absorption spectroscopy $\left(\lambda_{\max }=491 \mathrm{~nm}, \varepsilon=9,750 \mathrm{M}^{-1} \mathrm{~cm}^{-1}\right)$, which were consistent with other triarylformazans (Figs. S3, S4). ${ }^{5 \mathrm{~d}}$ Formazan 10 was transformed into its corresponding $\mathrm{BF}_{2}$ complex 11 by heating it in the presence of excess $\mathrm{BF}_{3} \cdot \mathrm{OEt}_{2}$ and $\mathrm{NEt}_{3}$ in toluene. This transformation was accompanied by a loss of the formazan $\mathrm{NH}$ resonance in the ${ }^{1} \mathrm{H}$ NMR spectrum and the appearance of a triplet $\left(-0.6 \mathrm{ppm},{ }^{1} J_{\mathrm{BF}}=29 \mathrm{~Hz}\right)$ and quartet $\left(-145.1 \mathrm{ppm},{ }^{1} J_{\mathrm{FB}}=29 \mathrm{~Hz}\right)$ in the ${ }^{11} \mathrm{~B}$ and ${ }^{19} \mathrm{~F} \mathrm{NMR}$ spectra collected for $\mathrm{BF}_{2}$ monomer 11 (Figs. S5-S8). The relatively low isolated yield of $53 \%$ for monomer $\mathbf{1 1}$ reflects our emphasis on purity, which was a priority given our desire to explore its subsequent polymerization reactivity. For many application, purification by column chromatography alone may be sufficient. 

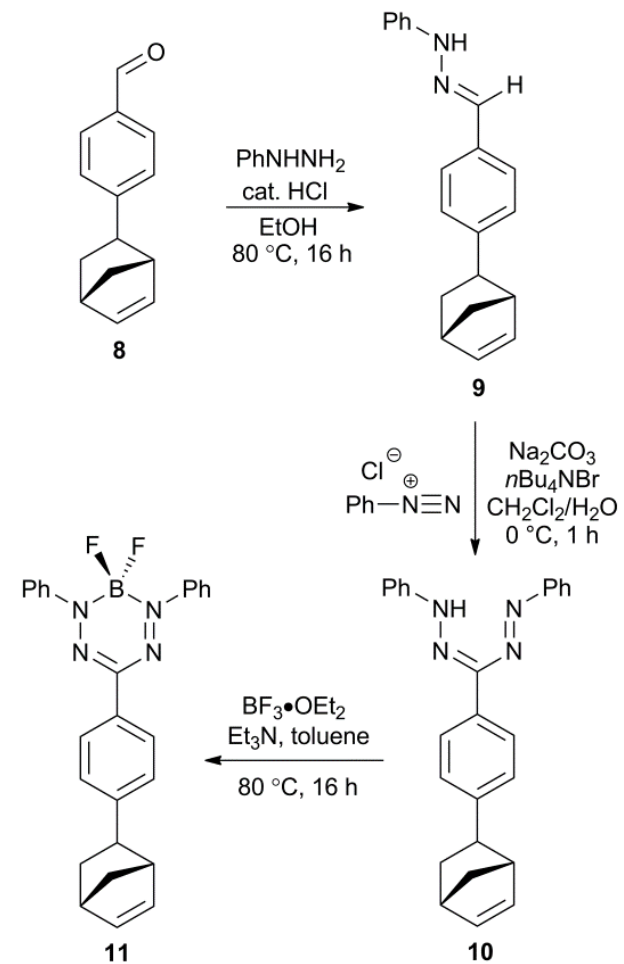

10

Scheme 1 Synthetic pathway for the realization of $\mathrm{BF}_{2}$ formazanate monomer 11.

Single crystals of monomer 11 (monoclinic, P 2 $1 / n$ ) were grown by diffusion of hexanes into a saturated solution in $\mathrm{CH}_{2} \mathrm{Cl}_{2}$ (Fig. 1, Table 1). The norbornene unit was disordered and two distinct occupancies at an angle of $77^{\circ}$ to one another were resolved. The solid-state structure of $\mathbf{1 1}$ shares many structural features in common with other $\mathrm{BF}_{2}$ triarylformazanate complexes. ${ }^{5 b, 5 d, 5 f}$ The N-N (N1-N2 1.316(2)

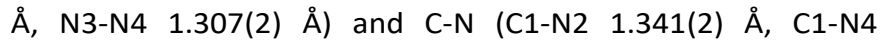
$1.350(2) \AA$ ) bond lengths of the formazanate ligand are essentially symmetric and in between the typical bond lengths of single and double bonds of the respective atoms. ${ }^{18}$ The $N$ aryl substituents are twisted by 52.9 and $49.5^{\circ}$ relative to the $\mathrm{N}_{4}$ plane, in what has been previously coined as a 'dragonfly' conformation. $^{5 \mathrm{C}}$ The $\mathrm{B} 1$ and $\mathrm{C} 1$ atoms are displaced from the $\mathrm{N}_{4}$ plane by 0.64 and $0.22 \AA$, which exists at a torsion angle of $30.5^{\circ}$ with respect to the $p$-substituted phenyl spacer (C14-C19). Based on the solid-state structure and related NMR spectra that are consistent with the presence of a single compound (Figs. S5-S8), we concluded that complex 11 exists exclusively as the exo-isomer.

\section{Polymer Synthesis and Characterization}

Based on the exceptional functional group tolerance and molecular weight control generally associated with ROMP, ${ }^{19}$ we chose to explore its suitability for the preparation of $\mathrm{BF}_{2}$ formazanate polymers. Our polymerization reactions were carried out at monomer concentrations of ca. $10 \mathrm{mg} \mathrm{mL}^{-1}$ in dry and degassed $\mathrm{CH}_{2} \mathrm{Cl}_{2}$ at $0{ }^{\circ} \mathrm{C}$ using Grubbs III (3-bromo-
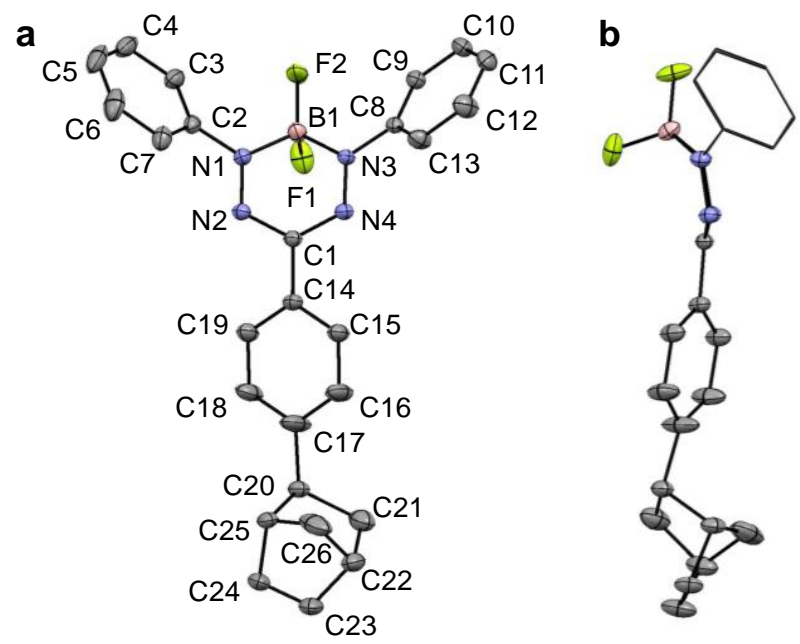

Fig. 1 Top (a) and side (b) views of the solid-state structure of $B F_{2}$ formazanate monomer 11. Selected bond lengths $(\AA)$ : N1-N2 1.316(2), N3-N4 1.307(2), C1-N2 1.341(2), C1-N4 1.350(2), N1-B1 1.553(3), N3B1 1.560(2), C20-C21 1.623(4), C23-C24 1.333(3). Selected bond angles (deg.): N1-N2-C1 116.3(1), N3-N4-C1 116.8(1), N1-B1-N3 100.9(1), N2C1-N4 124.1(1).

pyridine derivative) and ethyl vinyl ether as a capping/terminating agent according to Scheme $2 .^{20}$

In order to further probe the suitability of ROMP for the polymerization of monomer 11, we conducted two different kinetic studies. The scope of our studies was limited by the fact that the ${ }^{1} \mathrm{H}$ NMR resonances associated with the phenyl end group overlapped with those of the phenyl groups of the polymer repeating unit. Furthermore, the polymers described were found to absorb the $630 \mathrm{~nm}$ wavelength laser that we typically employ during light-scattering experiments. Nonetheless, we set out to monitor a ROMP reaction between monomer 11 and Grubbs III over a period of $8 \mathrm{~min}$ in order to construct a semi-logarithmic plot (Fig. 2). The linear nature of the plot, which was constructed using the ratios of the ${ }^{1} \mathrm{H} N M R$ integrations of the vinyl protons in the monomer $(\mathrm{m}$, 6.32-6.28 ppm and $\mathrm{m}, 6.23-6.19 \mathrm{ppm}$ ) and polymer (br s, 5.23
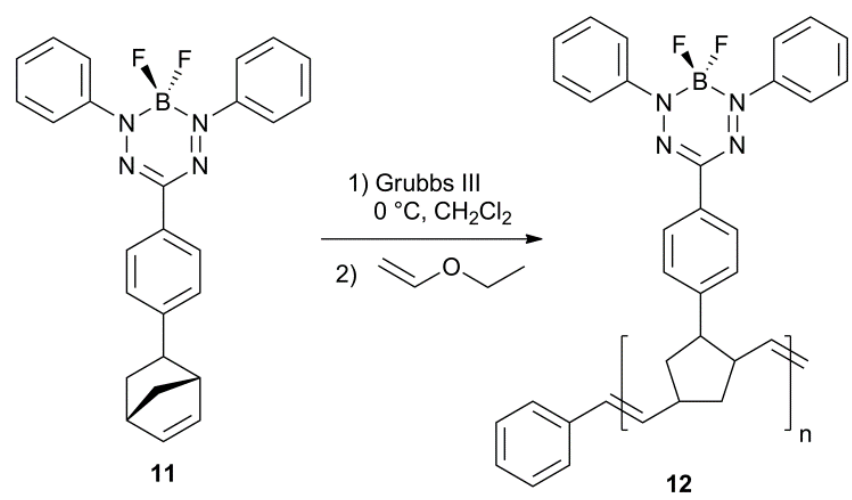

Scheme 2 Generic reaction scheme for the ROMP of $\mathrm{BF}_{2}$ formazanate monomer $\mathbf{1 1}$ to afford polymer $\mathbf{1 2}$. 


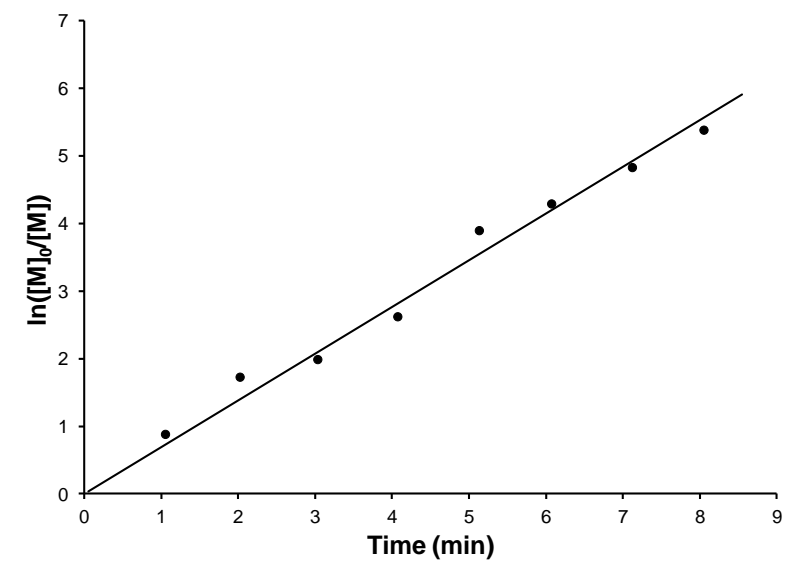

Fig. 2 Semilogarithmic plot for the consumption of $\mathrm{BF}_{2}$ formazanate monomer $\mathbf{1 1}$ as a function of time. The black line is a best fit trendline for the data.

ppm), confirmed that monomer consumption was consistent with living ROMP.

We conducted a second study designed to probe the relationship between feed molar ratio and the number average degree of polymerization $\left(D P_{n}\right)$, determined by conventional calibration GPC analysis (Fig. 3a, $M_{n}$ 9,250-69,000 $\left.\mathrm{g} \mathrm{mol}^{-1}, Ð 1.12-1.29\right)$. Despite previous indications that the ROMP of monomer $\mathbf{1 1}$ may occur in a living fashion, we observed a deviation from ideal polymerization behaviour during this second study. When high molecular weight polymers were targeted (lower catalyst:monomer ratios), lower than expected values of $D_{n}$ were observed. Furthermore, as the catalyst:monomer ratio was decreased, a high molecular weight shoulder began to appear in the corresponding GPC traces (Fig. 3b). Considering that the consumption of monomer $\mathbf{1 1}$ was consistent with a living ROMP, we postulate that, under the conditions employed, chain propagation competes with chain coupling reactions. The proposed chain coupling reactions would account for the larger high molecular weight shoulders observed as higher molecular weights were targeted. In order to probe this behaviour further, we stirred a purified sample of polymer 12 with Grubbs III under the same conditions employed for polymerization. Aliquots of the reaction mixture were removed after 5,15 , and $30 \mathrm{~min}$, terminated with ethyl vinyl ether, and passed through a neutral alumina column $\left(\mathrm{CH}_{2} \mathrm{Cl}_{2}\right)$ to remove the catalyst. GPC analysis revealed no change in the molecular weight distribution for each aliquot (Fig. S9), indicating that Grubbs III does not readily react with the unstrained alkenes present in the polymer backbone. Thus, we conclude that chain coupling must involve the propagating chain end exclusively. Furthermore, based on the monomer consumption studies discussed previously, we postulate that chain coupling does not result in catalyst poisoning. Similar chain coupling reactions were not reported when Grubbs III was employed for the polymerization of related redox-active monomers based on nitronyl nitroxide radicals ${ }^{10}$ and cobaltocenium moieties. ${ }^{21}$
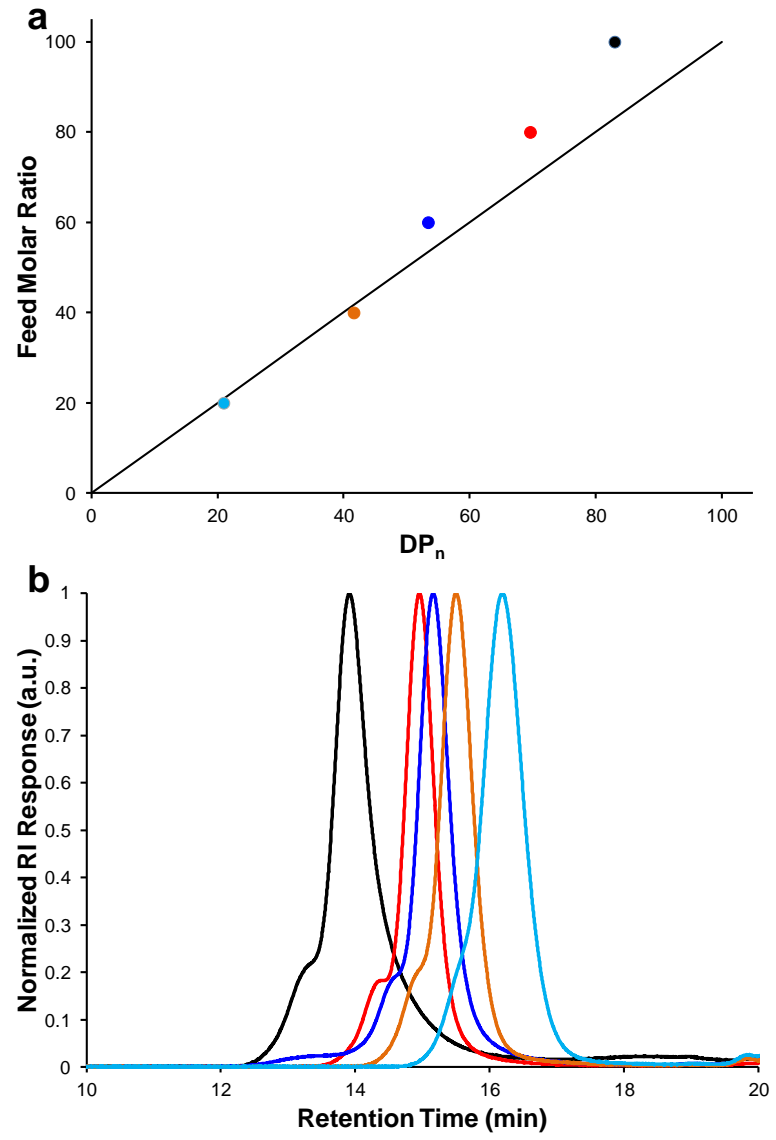

Fig. 3 Relationship between the $\mathrm{DP}_{\mathrm{n}}$ of $\mathrm{BF}_{2}$ formazanate polymer 12 determined by GPC analysis and the molar feedstock ratio (a) and corresponding GPC traces (b). The black line represents the theoretical relationship between feed molar ratio and $D P_{n}$.

Based on our kinetic studies, we prepared a sample of polymer 12 for comparison with monomer 11, stopping the polymerization reaction before complete conversion in order to minimize the degree of chain coupling and/or side reactivity (90\% isolated yield; GPC: $M_{n}=35,900 \mathrm{~g} \mathrm{~mol}^{-1}, M_{w}=41,450 \mathrm{~g}$ $\left.\mathrm{mol}^{-1}, \emptyset=1.15\right)$. The ${ }^{1} \mathrm{H}$ NMR spectrum of polymer 12 was broadened compared to that of monomer 11, and was comprised of resonances corresponding to the proposed structure (Fig. S10). The ${ }^{11} \mathrm{~B}$ and ${ }^{19} \mathrm{~F}$ NMR spectra of polymer 12 each contained two resonances that we believe correspond to head-to-tail (major) and head-to-head and/or tail-to-tail (minor) diads within the polymer backbone (Figs. S11, S12). Upon heating, polymer $\mathbf{1 2}$ degraded gradually up to a temperature of $237^{\circ} \mathrm{C}$, at which time it had lost $3 \%$ of its mass. Above $237{ }^{\circ} \mathrm{C}$, the polymer degraded in two steps corresponding to $32 \%$ and $40 \%$ mass loss, respectively. At 775 ${ }^{\circ} \mathrm{C}, 28 \%$ of the initial mass remained (Fig. S13). The glass transition temperature $\left(\mathrm{T}_{\mathrm{g}}\right)$ determined for polymer 12 was $161{ }^{\circ} \mathrm{C}$ (Fig. S14). 


\section{UV-Vis Absorption and Emission Spectroscopy}

The UV-Vis absorption and emission spectra collected for monomer $\mathbf{1 1}$ and polymer $\mathbf{1 2}$ in $\mathrm{CH}_{2} \mathrm{Cl}_{2}$ are quite similar (Fig. 4, $\mathrm{S} 15$, and S16). The lowest energy absorptions for both complexes occur at $\lambda_{\max }=518 \mathrm{~nm}\left(\varepsilon \sim 14,750 \mathrm{M}^{-1} \mathrm{~cm}^{-1}\right)$ and are red-shifted by $27 \mathrm{~nm}$ when compared to formazan 10 . The highest occupied molecular orbital (HOMO) and lowest unoccupied molecular orbital (LUMO) have previously been shown as the dominant orbital pair $\left(\pi \rightarrow \pi^{*}\right)$ involved in the lowest energy excitation computed for similar compounds using time-dependent density functional theory (TDDFT). ${ }^{\text {5e }}$ The close agreement of the spectra confirms that the pendant $\mathrm{BF}_{2}$ formazanate groups of polymer 12 tolerate the ROMP reaction, and also that through space electron transfer does not occur readily along the polymer backbone. The thin-film absorption spectrum of polymer $\mathbf{1 2}$ was red-shifted, but qualitatively very similar to the solution-based spectrum (Fig. $4 b)$, further confirming that the side-chain $\mathrm{BF}_{2}$ formazanate groups are electronically isolated in the polymer. Both monomer and polymer are weakly emissive in solution, with wavelengths of maximum emission $\left(\lambda_{\mathrm{em}}\right)$ of $645 \mathrm{~nm}$ and quantum yields $\left(\Phi_{F}\right)$ of $1.5 \%$ for 11 and $2.5 \%$ for $12 .{ }^{22}$ The large Stoke's shifts (U $U_{\text {ST }}$ ) of $127 \mathrm{~nm}\left(3,800 \mathrm{~cm}^{-1}\right.$ ) are consistent with other $\mathrm{BF}_{2}$ complexes of triarylformazanates, ${ }^{5 \mathrm{~d}}$ and we are actively exploring the origin of this phenomena in our laboratory. Compared to similar side-chain BODIPY polymers [e.g., 4: $\lambda_{\max }=520 \mathrm{~nm}, \lambda_{\text {em }}=540 \mathrm{~nm}, \Phi_{\mathrm{F}}=0.37, \mathrm{U}_{\mathrm{ST}}=20 \mathrm{~nm}$ $\left.\left.\left(712 \mathrm{~cm}^{-1}\right)\right]\right]^{3 \mathrm{~d}}$ the absorption and emission maxima of polymer 12 were red-shifted, the observed fluorescence intensity (quantum yield) was significantly lower, and the Stoke's shift was significantly larger.

\section{Cyclic Voltammetry}

The electrochemical properties of $\mathrm{BF}_{2}$ formazanate monomer 11 and polymer 12 were examined by conducting cyclic voltammetry (CV) studies in $\mathrm{CH}_{2} \mathrm{Cl}_{2}$ and THF (Figs. 5, S17, and $\mathrm{S} 18)$. Upon scanning to negative potentials, monomer $\mathbf{1 1}$ undergoes two one-electron reductions to form its ligandcentred radical anion $\left(E_{\text {red1 }}^{\circ}=-0.97 \mathrm{mV} ; \mathrm{LBF}_{2} \leftrightarrows \mathrm{LBF}_{2}{ }^{--}, \mathrm{L}=\right.$ formazanate ligand) and dianion $\left(E_{\text {red2 }}^{\circ}=-1.92 \mathrm{~V}^{\circ} \mathrm{LBF}_{2}{ }^{--} \rightarrow\right.$ $\mathrm{LBF}_{2}{ }^{2-}$ ) forms. The second reduction is not formally reversible, indicating that the extremely electron-rich dianion formed undergoes a chemical reaction on the timescale of the CV experiment. Crucially, based on the fact that the first reduction wave is reversible, this chemical reaction must regenerate the radical anion form of monomer $\mathbf{1 1}$, which is subsequently oxidized to form the neutral form of monomer 11. The observed behaviour is consistent with previous reports for similar compounds, ${ }^{5 f}$ but differs from the reactivity pathways previously described by Otten and co-workers, whereby a number of unique products were observed upon chemical reduction with $\mathrm{Na} / \mathrm{Hg}$ amalgum. ${ }^{5 \mathrm{~g}}$ The $\mathrm{CV}$ of polymer 12 illustrates significantly different behaviour. The first reduction wave $\left(E_{\text {red1 }}^{\circ}=-0.95 \mathrm{~V}\right.$ ) is broadened compared to what was observed for monomer 11, and the current response was significantly lower than expected. Both observations are
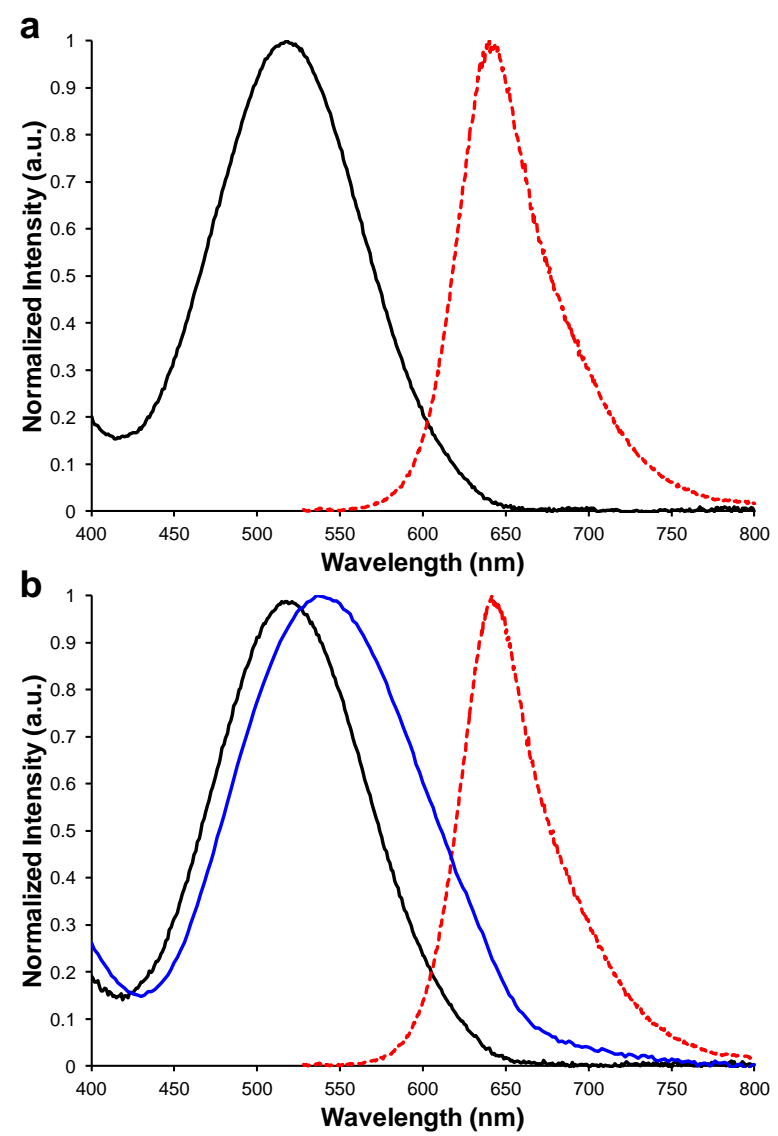

Fig. 4 Solution phase UV-Vis absorption (black lines) and emission (red, dashed lines) spectra recorded in $\mathrm{CH}_{2} \mathrm{Cl}_{2}$ and thin-film UV-Vis absorption spectrum (blue line) of $\mathrm{BF}_{2}$ formazanate monomer $\mathbf{1 1}$ (a) and polymer 12 (b).

consistent with a lack of diffusion control at the working electrode, a common problem encountered when analyzing macromolecules. Of particular significance is the absence of a second reduction wave for the polymer. Upon conversion of the neutral form of polymer $\mathbf{1 2}$ to its poly(radical anion) form, we believe that each repeating unit of the polymer exists in an

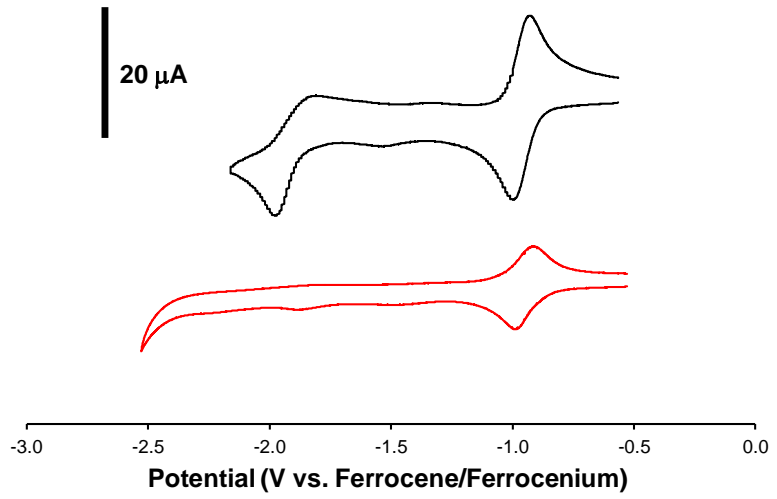

Fig. 5 Cyclic voltammograms for $\mathrm{BF}_{2}$ formazanate monomer $\mathbf{1 1}$ (black line) and polymer 12 (red line) recorded in dry, degassed $\mathrm{CH}_{2} \mathrm{Cl}_{2}$ containing $\sim 1 \mathrm{mM}$ analyte and $0.1 \mathrm{M} \mathrm{nBu}_{4} \mathrm{NPF}_{6}$ at a scan rate of $250 \mathrm{mV} \mathrm{s}^{-1}$. 
extremely electron-rich environment due to the close proximity of neighbouring anions along the polymer backbone. We assume that the second reduction would occur outside of the electrochemical window for $\mathrm{CH}_{2} \mathrm{Cl}_{2}$ and $\mathrm{THF}$, and is therefore not observed. The reversibility of the first reduction wave supports our argument and disfavours alternative explanations involving decomposition of the poly(radical anion) form of the polymer.

\section{Conclusions}

We have thoroughly investigated the ROMP of a novel norbornene-containing $\mathrm{BF}_{2}$ formazanate monomer. During the polymerization, which readily occurs in the presence of $\mathrm{BF}_{2}$ formazantes, monomer $\mathbf{1 1}$ is consumed in a fashion consistent with a living polymerization. However, studies involving variation of the feed molar ratio revealed a loss of control when higher molecular weights were targeted, indicating that chain coupling and/or side reactions compete with chain propagation. The absorption/emission properties of the resulting polymer $\mathbf{1 2}$, which can be prepared with reasonable molecular weight control, were in close agreement with those of the monomer. CV studies revealed significantly different behaviour, whereby the expected reduction of the polymer from the poly(radical anion) form to the poly(dianion) form was not observed, presumably due to the extremely electronrich environment created upon the initial reduction of the polymer. Our future work in this area will involve expansion of the methodologies described to include a wide range of $\mathrm{BF}_{2}$ formazanate polymers and exploration of their redox and light harvesting properties.

\section{Acknowledgements}

We would like to thank the University of Western Ontario, the Natural Science and Engineering Research Council (NSERC) of Canada (J.B.G.: DG, 435675 and S.N., J.A.P., S.M.B., R.R.M.: postgraduate scholarships), and the Ontario Ministry of Research and Innovation (J.B.G.: ERA, ER14-10-147) for funding this work. Finally, we thank Dr. Elizabeth R. Gillies and Dr. Paul J. Ragogna for access to instrumentation in their laboratories.

\section{Notes and references}

1 Review: X. He and T. Baumgartner, RSC Adv., 2013, 3, 1133411350.

2 Selected examples: (a) A. Lorbach, M. Bolte, H. Li, H.-W. Lerner, M. C. Holthausen, F. Jäkle and M. Wagner, Angew. Chem. Int. Ed., 2009, 48, 4584-4588; (b) B. Kim, B. Ma, V. R. Donuru, H. Liu and J. M. J. Fréchet, Chem. Commun., 2010, 46, 4148-4150; (c) D. R. Levine, M. A. Siegler and J. D. Tovar, J. Am. Chem. Soc., 2014, 136, 7132-7139; (d) S. Zhang, Y. Sheng, G. Wei, Y. Quan, Y. Cheng and C. Zhu, J. Polym. Sci., Part A: Polym. Chem., 2014, 52, 1686-1692; (e) R. Yoshii, A. Hirose, K. Tanaka and Y. Chujo, J. Am. Chem. Soc., 2014, 136, 18131-18139; (f) R. Yoshii, H. Yamane, K. Tanaka and Y. Chujo, Macromolecules, 2014, 47,
3755-3760; (g) I. A. Adams and P. A. Rupar, Macromol. Rapid Commun., 2015, 36, 1336-1340; (h) C. Dai, D. Yang, X. Fu, Q. Chen, C. Zhu, Y. Cheng and L. Wang, Polym. Chem., 2015, 6, 5070-5076; (i) C.-T. Poon, D. Wu, W. H. Lam and V. W.-W. Yam, Angew. Chem. Int. Ed., 2015, 54, 10569-10573; (j) V. M. Suresh, A. Bandyopadhyay, S. Roy, S. K. Pati and T. K. Maji, Chem. Eur. J., 2015, 21, 10799-10804.

3 Selected examples: (a) R. Stahl, C. Lambert, C. Kaiser, R. Wortmann and R. Jakober, Chem. Eur. J., 2006, 12, 2358-2370; (b) C.-H. Zhao, A. Wakamiya and S. Yamaguchi, Macromolecules, 2007, 40, 3898-3900; (c) D. Reitzenstein and C. Lambert, Macromolecules, 2009, 42, 773-782; (d) A. Nagai, K. Kokado, J. Miyake and Y. Chujo, Macromolecules, 2009, 42, 5446-5452; (e) Y. Hu, Z. Zhao, X. Bai, X. Yuan, X. Zhang and T. Masuda, RSC Adv., 2014, 4, 55179-55186; (f) F. Guo, X. Yin, F. Pammer, F. Cheng, D. Fernandez, R. A. Lalancette and F. Jäkle, Macromolecules, 2014, 47, 7831-7841; (g) B. Liu, L. Li, C. Lin, J. Zhou, Z. Zhu, H. Xu, H. Qiu and S. Yin, Polym. Chem., 2014, 5, 372-381; (h) H. Yeo, K. Tanaka and Y. Chujo, J. Polym. Sci., Part A: Polym. Chem., 2015, 53, 2026-2035.

4 Reviews: (a) C. D. Entwistle and T. B. Marder, Chem. Mater., 2004, 16, 4574-4585; (b) N. Matsumi and Y. Chujo, Polym. J., 2008, 40, 77-89; (c) F. Jäkle, Chem. Rev., 2010, 110, 3985-4022.

5 Selected examples: (a) J. B. Gilroy, M. J. Ferguson, R. McDonald, B. O. Patrick and R. G. Hicks, Chem. Commun., 2007, 126-128; (b) M.-C. Chang and E. Otten, Chem. Commun., 2014, 50, 74317433; (c) S. M. Barbon, P. A. Reinkeluers, J. T. Price, V. N. Staroverov and J. B. Gilroy, Chem. Eur. J., 2014, 20, 1134011344; (d) S. M. Barbon, J. T. Price, P. A. Reinkeluers and J. B. Gilroy, Inorg. Chem., 2014, 53, 10585-10593; (e) S. M. Barbon, V. N. Staroverov and J. B. Gilroy, J. Org. Chem., 2015, 80, 52265235; (f) S. M. Barbon, J. T. Price, U. Yogarajah and J. B. Gilroy, RSC Adv., 2015, 5, 56316-56324; (g) M.-C. Chang and E. Otten, Inorg. Chem., 2015, 54, 8656-8664; (h) R. R. Maar, S. M. Barbon, N. Sharma, H. Groom, L. G. Luyt and J. B. Gilroy, Chem. Eur. J., 2015, 21, 15589-15599.

6 Selected examples: (a) D. A. Brown, H. Bögge, G. N. Lipunova, A. Müller, W. Plass and K. G. Walsh, Inorg. Chim. Acta, 1998, 280, 30-38; (b) J. B. Gilroy, B. O. Patrick, R. McDonald and R. G. Hicks, Inorg. Chem., 2008, 47, 1287-1294; (c) S. Hong, L. M. R. Hill, A. K. Gupta, B. D. Naab, J. B. Gilroy, R. G. Hicks, C. J. Cramer and W. B. Tolman, Inorg. Chem., 2009, 48, 4514-4523; (d) M.-C. Chang, T. Dann, D. P. Day, M. Lutz, G. G. Wildgoose and E. Otten, Angew. Chem. Int. Ed., 2014, 53, 4118-4122; (e) R. Travieso-Puente, M.C. Chang and E. Otten, Dalton Trans., 2014, 43, 18035-18041; (f) M.-C. Chang, P. Roewen, R. Travieso-Puente, M. Lutz and E. Otten, Inorg. Chem., 2015, 54, 379-388; (g) N. A. Protasenko, A. I. Poddel'sky, A. S. Bogomyakov, G. K. Fukin and V. K. Cherkasov, Inorg. Chem., 2015, 54, 6078-6080.

7 Reviews: (a) A. W. Nineham, Chem. Rev., 1955, 55, 355-483; (b) A. S. Shawali and N. A. Samy, J. Adv. Res., 2015, 6, 241-254.

8 Review: L. Bourget-Merle, M. F. Lappert and J. R. Severn, Chem. Rev., 2002, 102, 3031-3066.

9 M. Hesari, S. M. Barbon, V. N. Staroverov, Z. Ding and J. B. Gilroy, Chem. Commun., 2015, 51, 3766-3769.

10 T. Sukegawa, A. Kai, K. Oyaizu and H. Nishide, Macromolecules, 2013, 46, 1361-1367. 
11 K. Suzuki, A. Kobayashi, S. Kaneko, K. Takehira, T. Yoshihara, H. Ishida, Y. Shiina, S. Oishi and S. Tobita, Phys. Chem. Chem. Phys., 2009, 11, 9850-9860.

12 S. Fery-Forgues and D. Lavabre, J. Chem. Educ., 1999, 76, 12601264.

13 Bruker-AXS, SAINT version 2013.8, 2013, Bruker-AXS, Madison, WI 53711, USA.

14 Bruker-AXS, SADABS version 2012.1, 2012, Bruker-AXS, Madison, WI 53711, USA.

15 G. M. Sheldrick, Acta Crystallogr., 2015, A71, 3-8.

16 G. M. Sheldrick, Acta Crystallogr., 2008, A64, 112-122.

17 A. A. Katritzky, S. A. Belyakov, D. Cheng and H. D. Durst, Synthesis, 1995, 1995, 577-581.
18 W. M. Haynes, CRC Handbook of Chemistry and Physics, CRC Press, Boca Raton, Fla, 2012.

19 Reviews: (a) C. W. Bielawski and R. H. Grubbs, Prog. Polym. Sci., 2007, 32, 1-29; (b) F. Blank and C. Janiak, Coord. Chem. Rev., 2009, 253, 827-861; (c) S. Sutthasupa, M. Shiotsuki and F. Sanda, Polym. J., 2010, 42, 905-915.

20 At monomer concentrations exceeding $10 \mathrm{mg} \mathrm{mL}^{-1}$, polymerization reactions went to completion in 1-2 $\mathrm{min}$ and broadened molecular weight distributions were observed.

21 L. Ren, J. Zhang, X. Bai, C. G. Hardy, K. D. Shimizu and C. Tang, Chem. Sci., 2012, 3, 580-583.

22 Thin films of polymer $\mathbf{1 2}$ were non-emissive under long-wave UV irradiation $(365 \mathrm{~nm})$. 


\section{Supplementary Information}

\section{Side-Chain Boron Difluoride Formazanate Polymers via Ring- Opening Metathesis Polymerization}

Samantha Novoa, Joseph A. Paquette, Stephanie M. Barbon, Ryan R. Maar and Joe B. Gilroy*

Department of Chemistry and the Centre for Advanced Materials and Biomaterials Research (CAMBR), The University of Western Ontario, 1151 Richmond St. N., London, Ontario, Canada, N6A 5B7. Tel: +1-519-661-2111 ext. 81561, E-mail: joe.gilroy@uwo.ca. 


\section{Emission Correction Data}

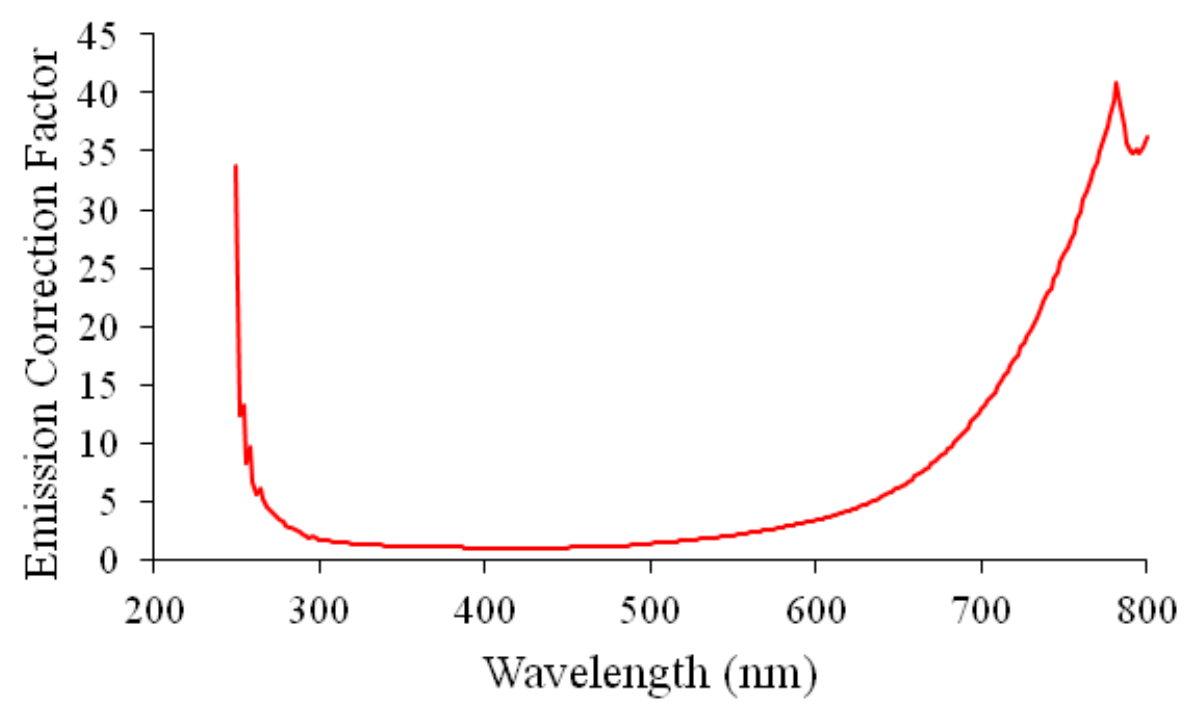

Fig. S1 Wavelength-dependent emission correction provided by Photon Technology International.

\section{NMR Spectra}

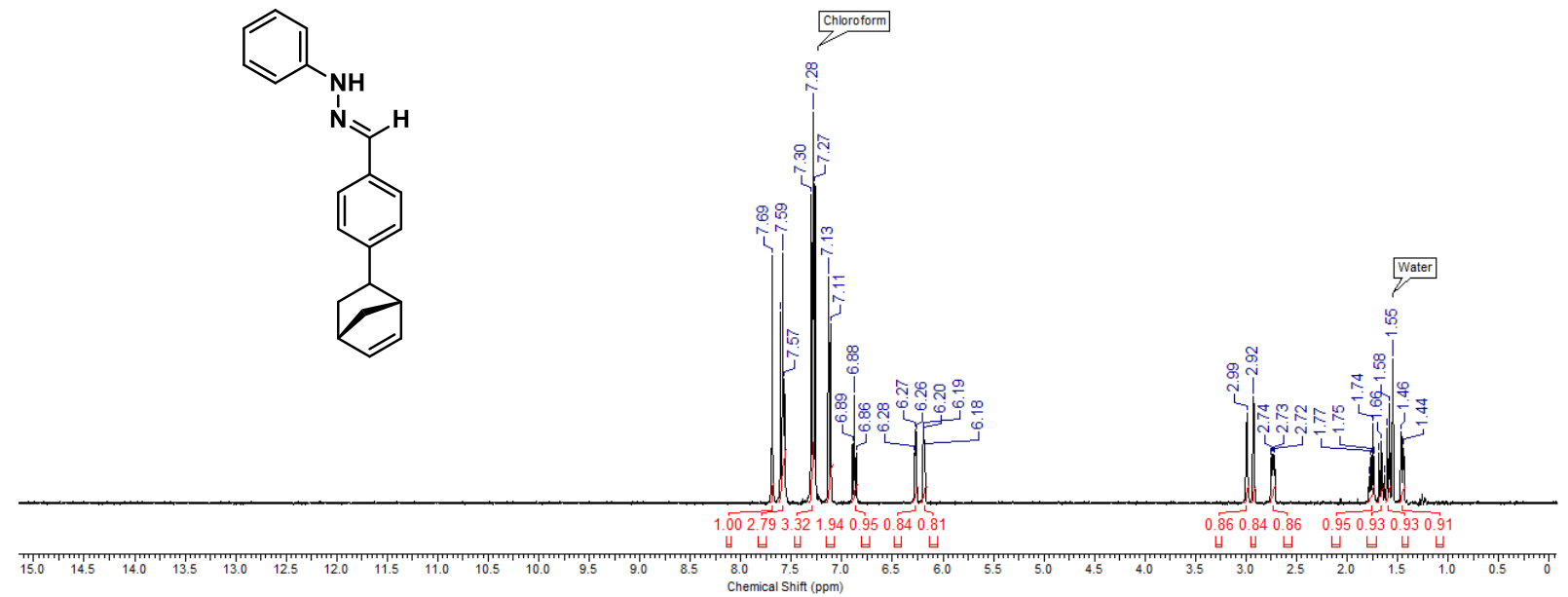

Fig. S2 $\quad{ }^{1} \mathrm{H}$ NMR spectrum of hydrazone 9 in $\mathrm{CDCl}_{3}$. 


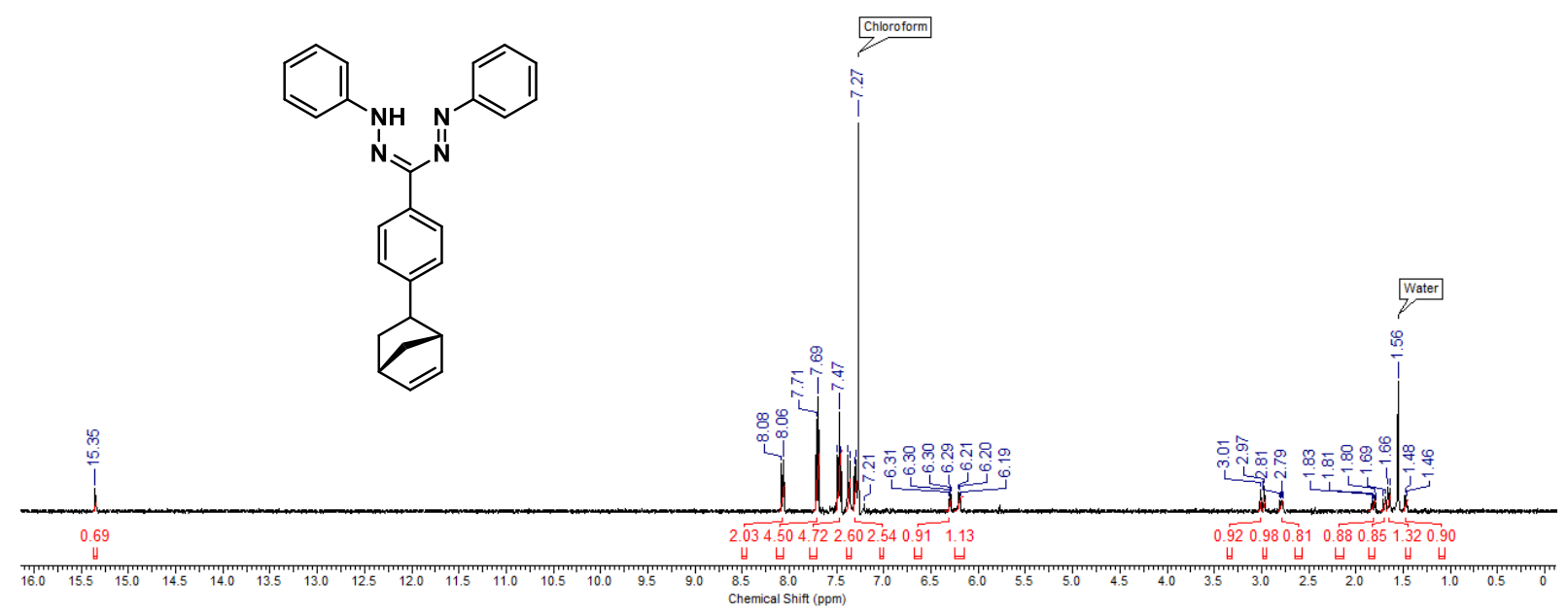

Fig. S3 ${ }^{1} \mathrm{H}$ NMR spectrum of formazan $\mathbf{1 0}$ in $\mathrm{CDCl}_{3}$.

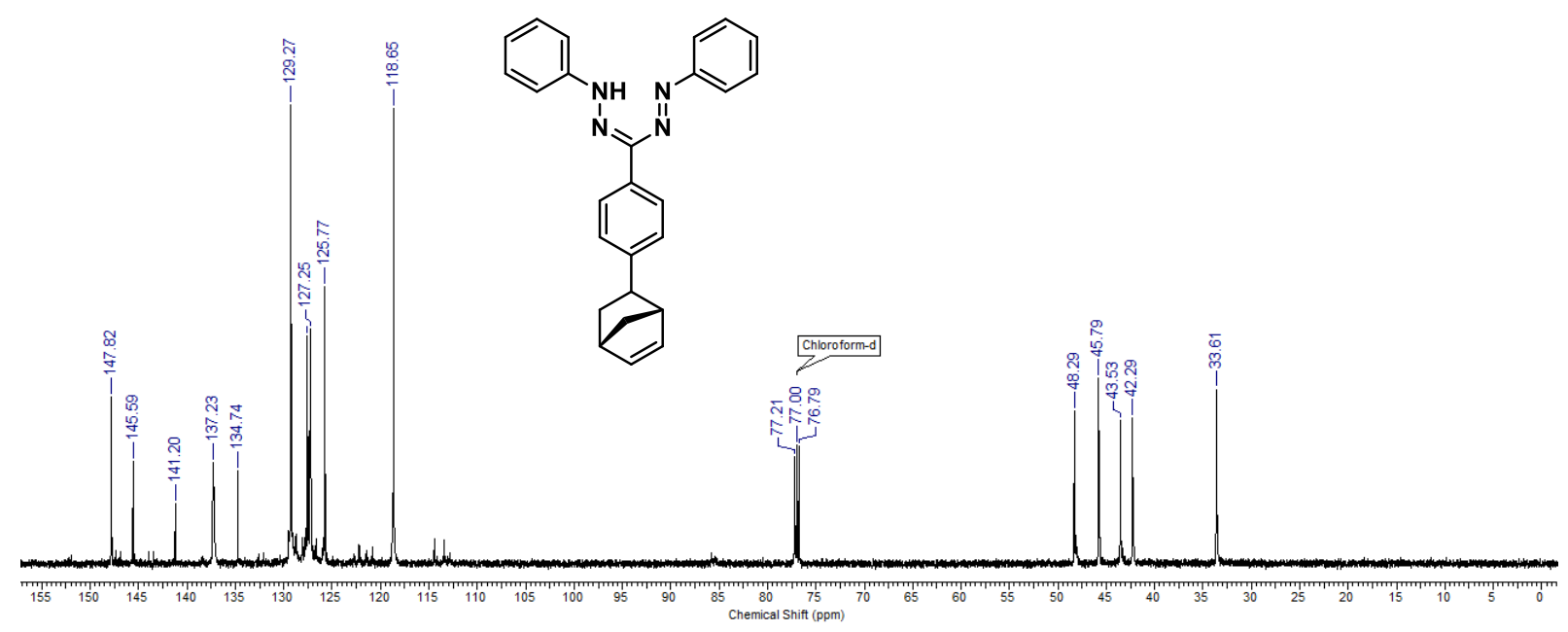

Fig. S4 $\quad{ }^{13} \mathrm{C}\left\{{ }^{1} \mathrm{H}\right\}$ NMR spectrum of formazan $\mathbf{1 0}$ in $\mathrm{CDCl}_{3}$. 


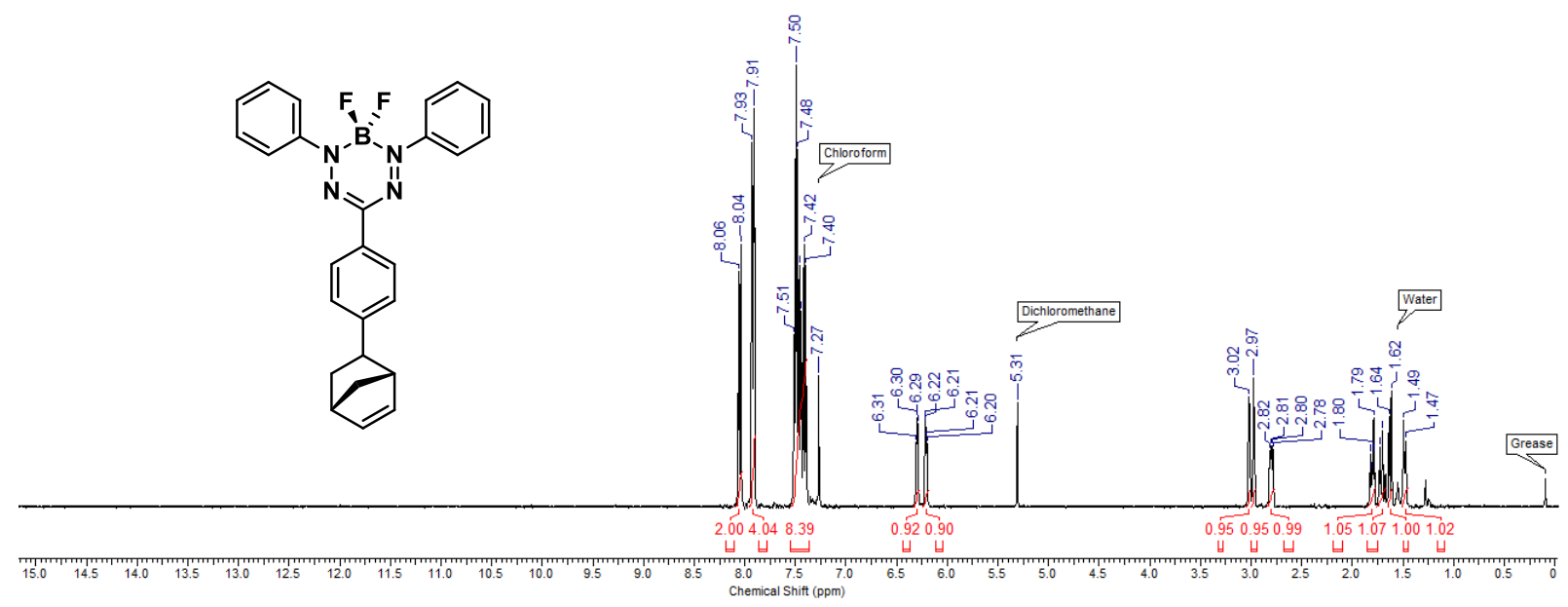

Fig. S5 ${ }^{1} \mathrm{H}$ NMR spectrum of $\mathrm{BF}_{2}$ formazanate monomer 11 in $\mathrm{CDCl}_{3}$.

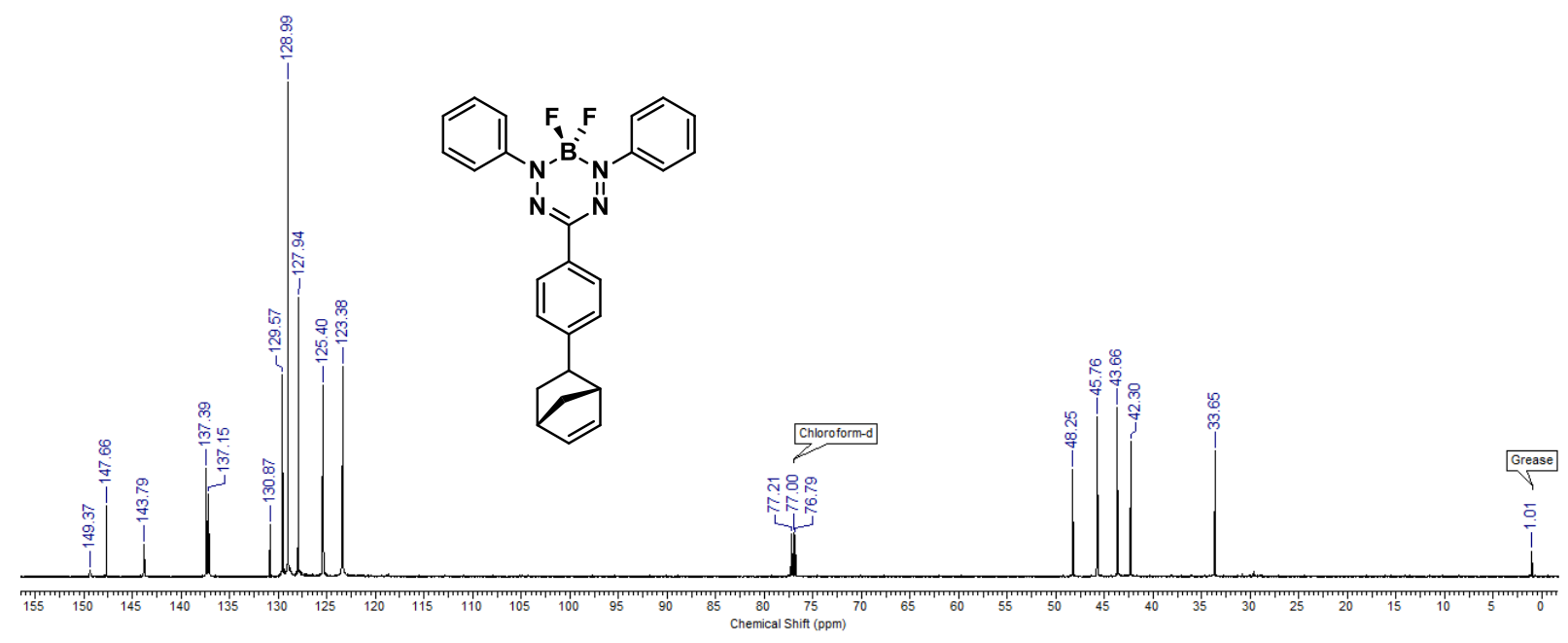

Fig. S6 $\quad{ }^{13} \mathrm{C}\left\{{ }^{1} \mathrm{H}\right\}$ NMR spectrum of $\mathrm{BF}_{2}$ formazanate monomer 11 in $\mathrm{CDCl}_{3}$. 


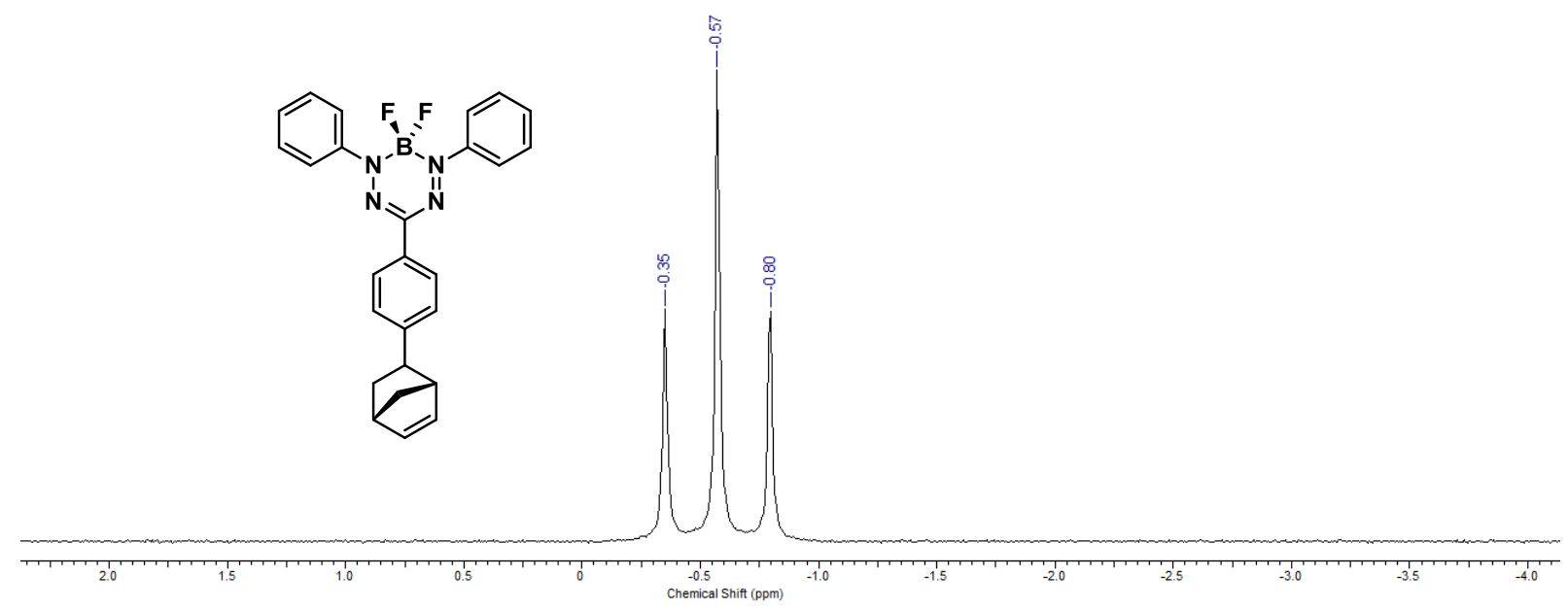

Fig. S7 $\quad{ }^{11} \mathrm{~B}$ NMR spectrum of $\mathrm{BF}_{2}$ formazanate monomer 11 in $\mathrm{CDCl}_{3}$.

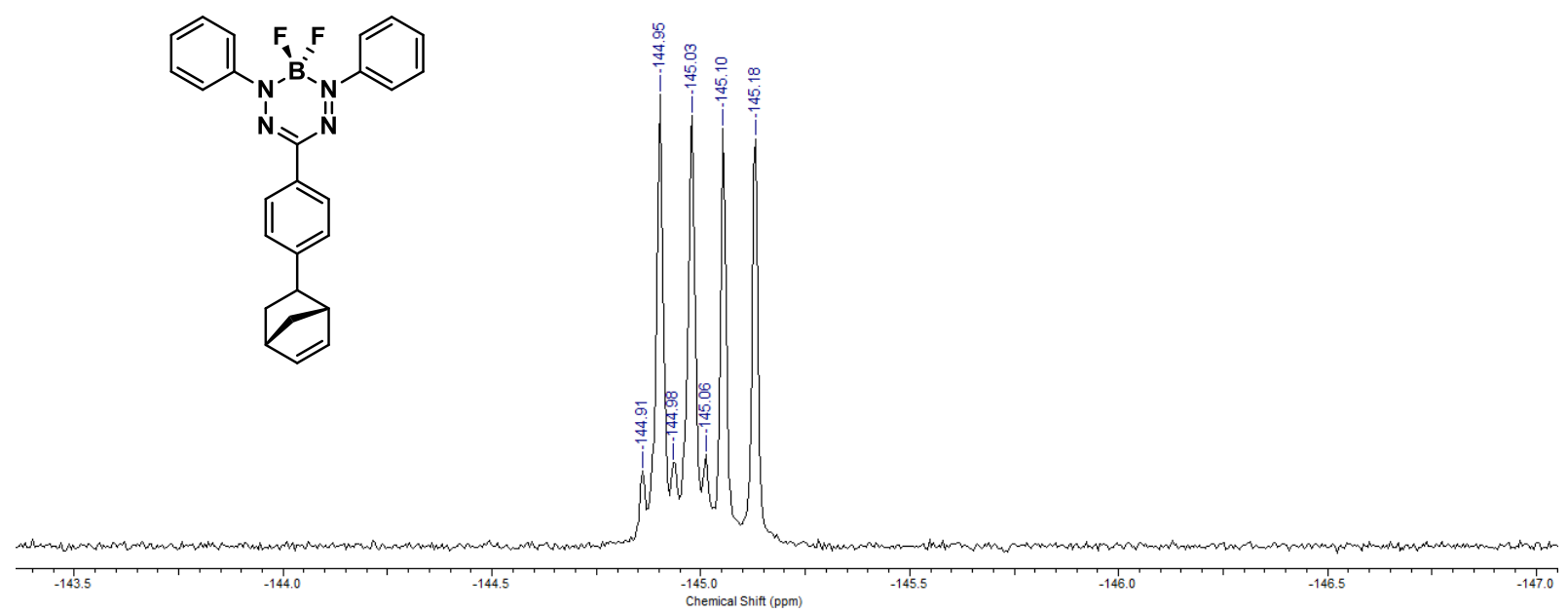

Fig. S8 $\quad{ }^{19} \mathrm{~F}$ NMR spectrum of $\mathrm{BF}_{2}$ formazanate monomer 11 in $\mathrm{CDCl}_{3}$. 


\section{Additional GPC Data}

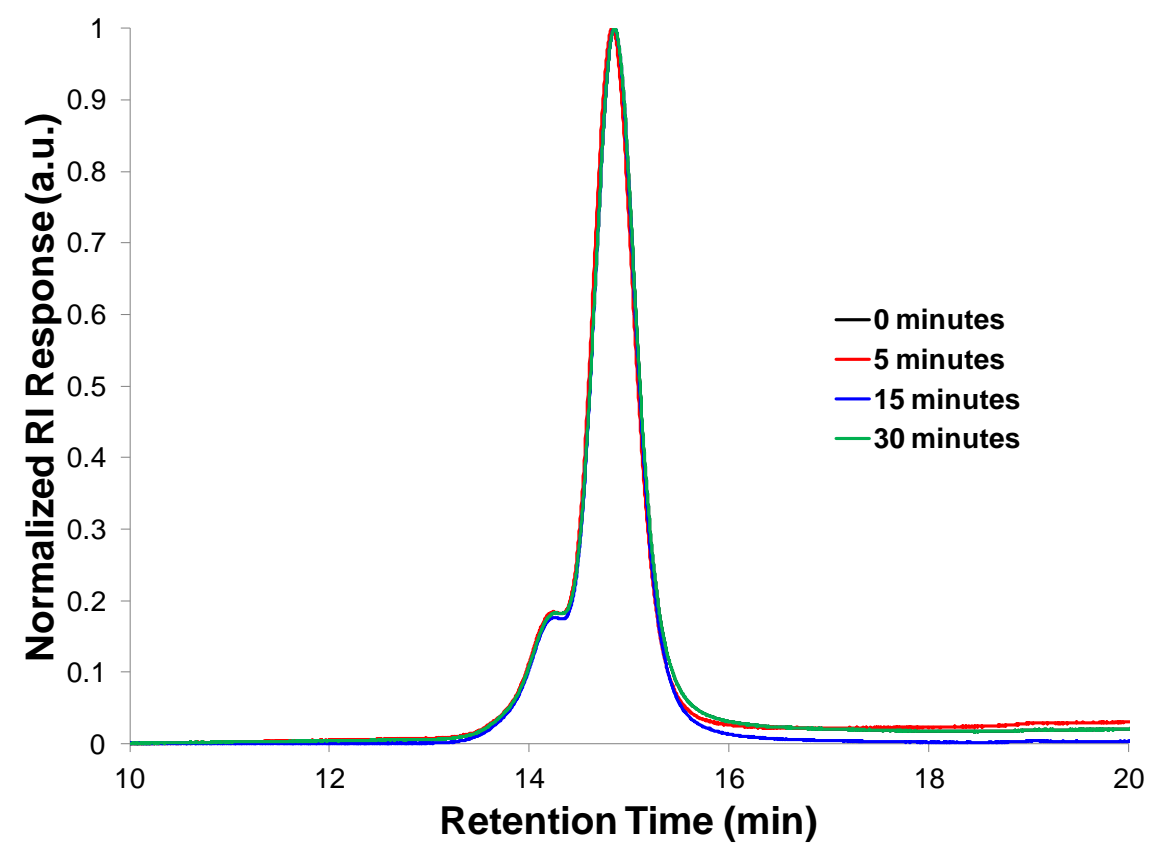

Fig. S9 GPC Traces for Control Experiment Involving the Reaction of Grubbs' 3rd Generation Catalyst with Polymer 12.

\section{Polymer NMR Data}

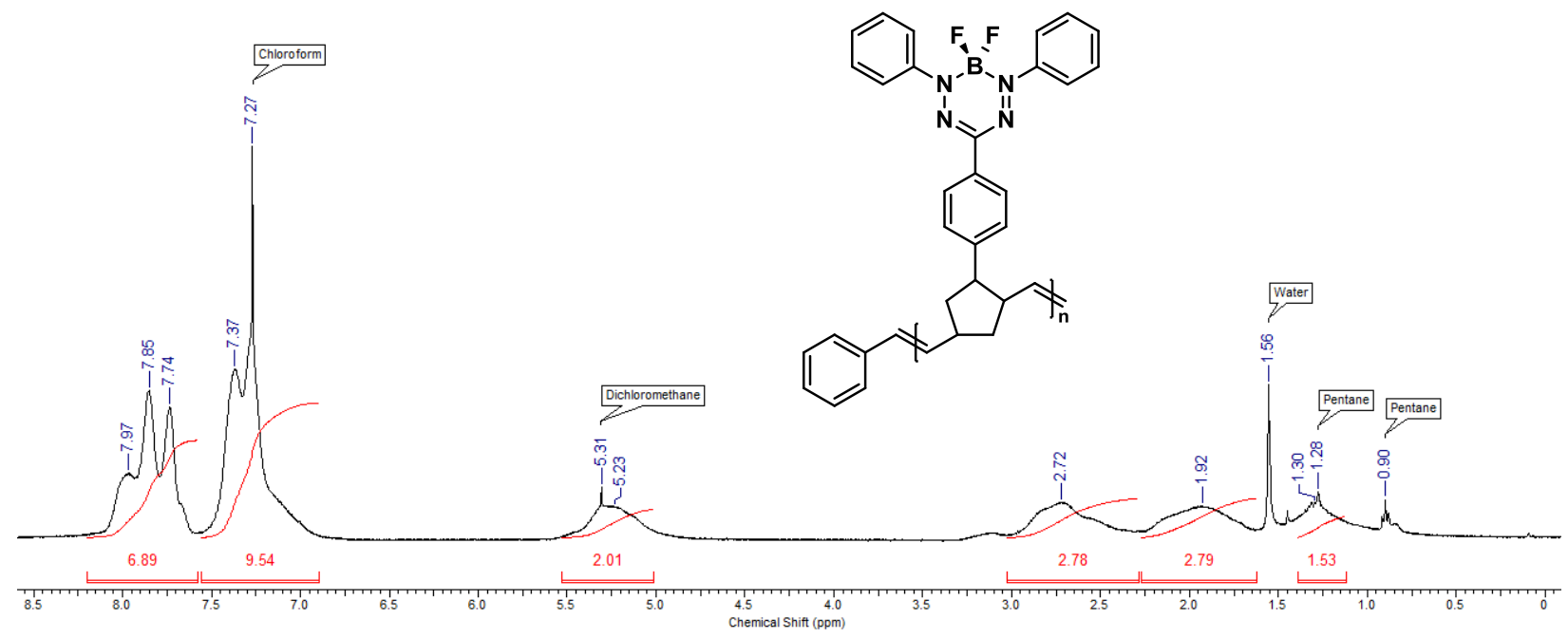

Fig. S10 $\quad{ }^{1} \mathrm{H}$ NMR spectrum of $\mathrm{BF}_{2}$ formazanate polymer 12 in $\mathrm{CDCl}_{3}$. 


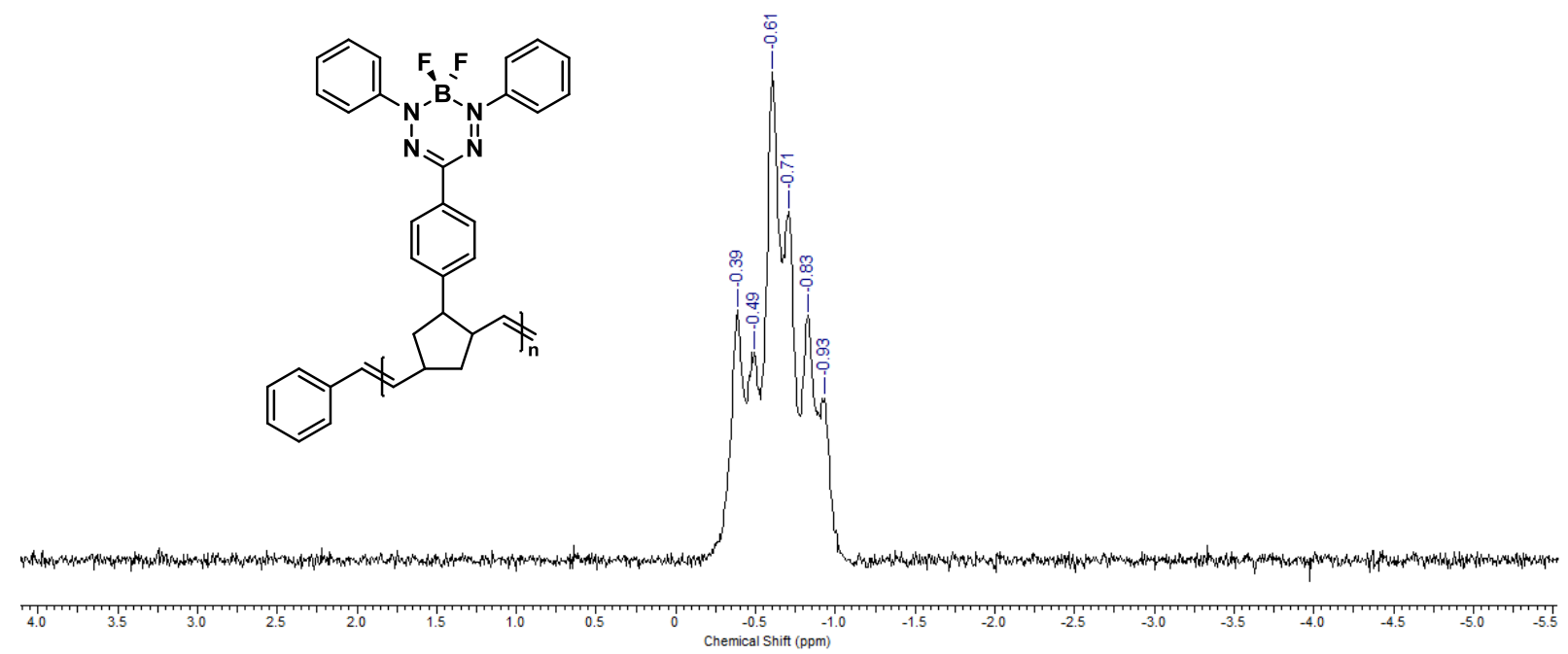

Fig. S11 ${ }^{11} \mathrm{~B}$ NMR spectrum of $\mathrm{BF}_{2}$ formazanate polymer 12 in $\mathrm{CDCl}_{3}$.
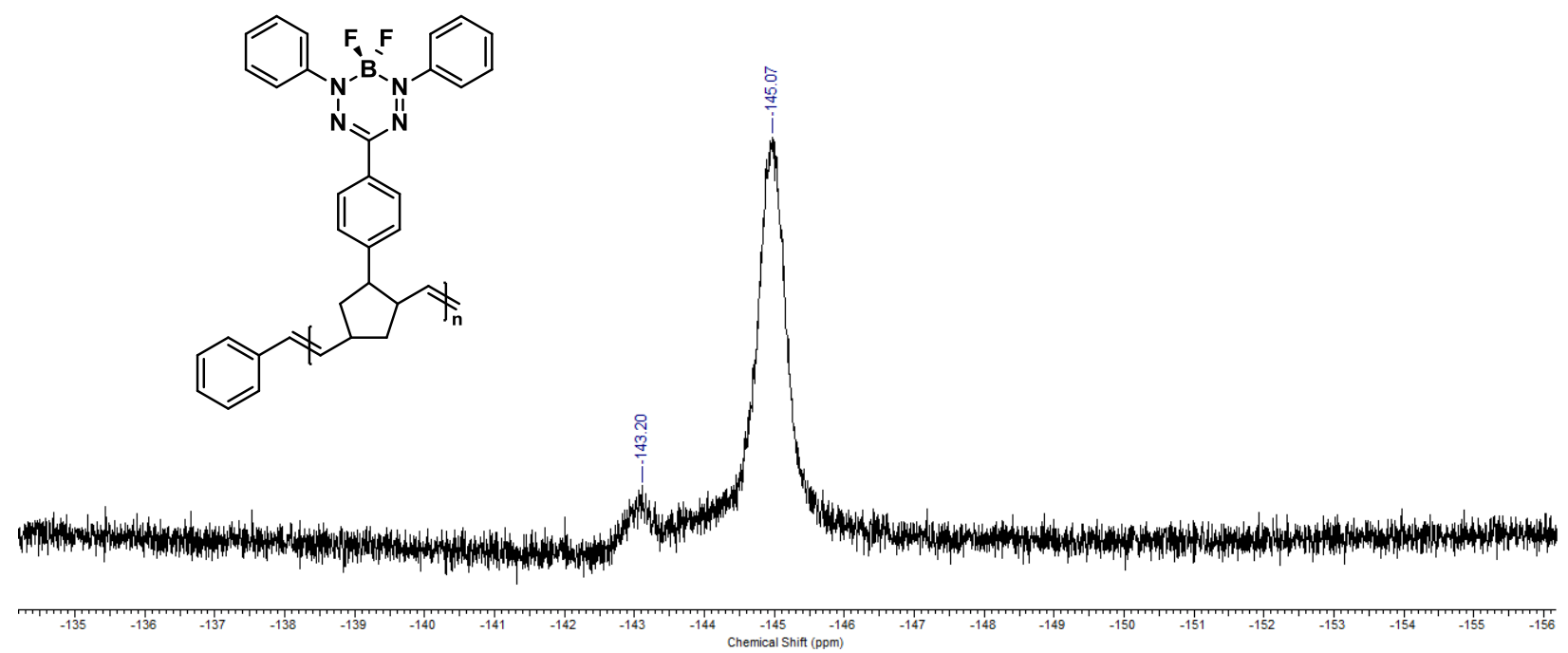

Fig. S12 ${ }^{19} \mathrm{~F}$ NMR spectrum of $\mathrm{BF}_{2}$ formazanate polymer 12 in $\mathrm{CDCl}_{3}$. 


\section{Thermal Analysis}

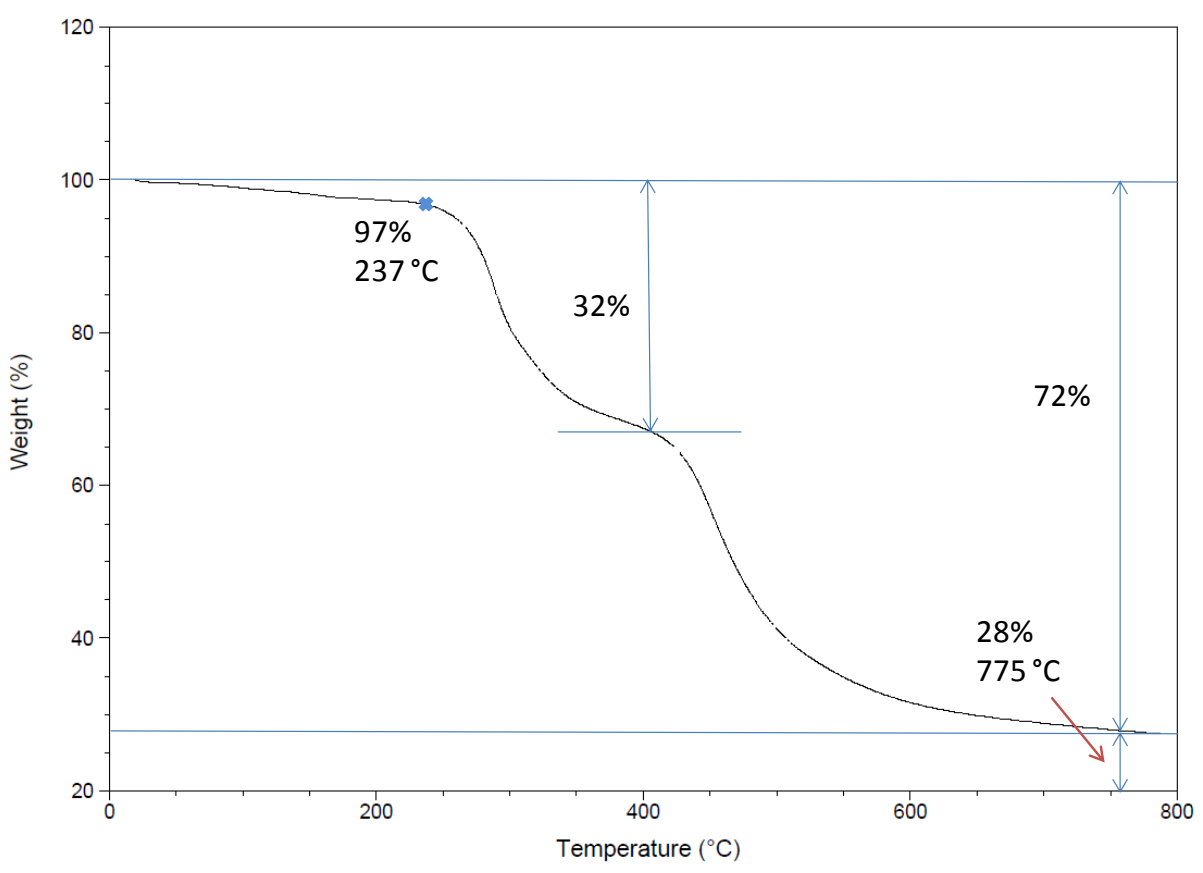

Fig. S13 TGA trace for $\mathrm{BF}_{2}$ formazanate polymer 12 .

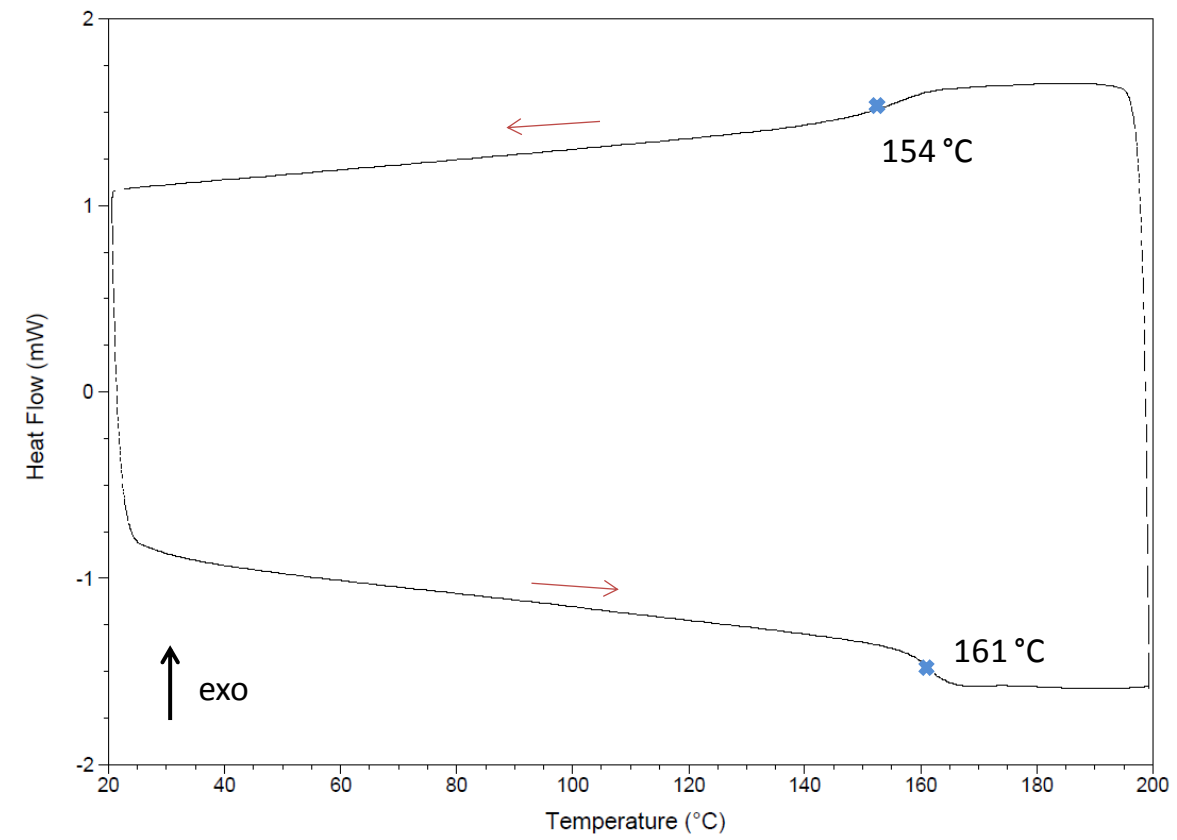

Fig. S14 DSC thermogram collected for $\mathrm{BF}_{2}$ formazanate polymer 12. 


\section{UV-Vis Absorption Spectra}

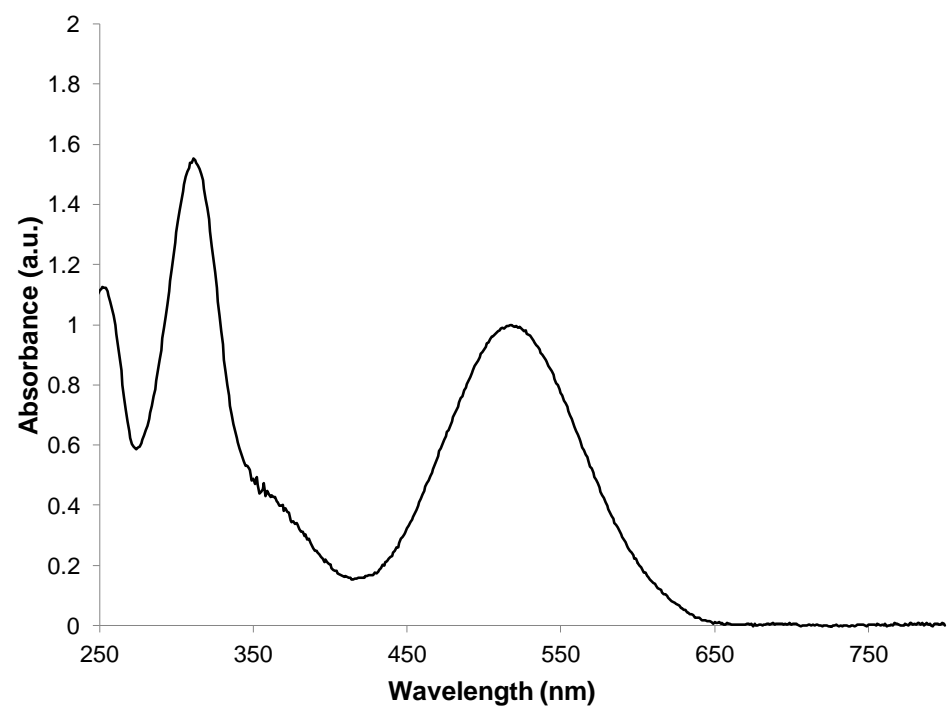

Fig. S15 UV-Vis absorption spectrum of $\mathrm{BF}_{2}$ formazanate monomer 11 recorded in $\mathrm{CH}_{2} \mathrm{Cl}_{2}$.

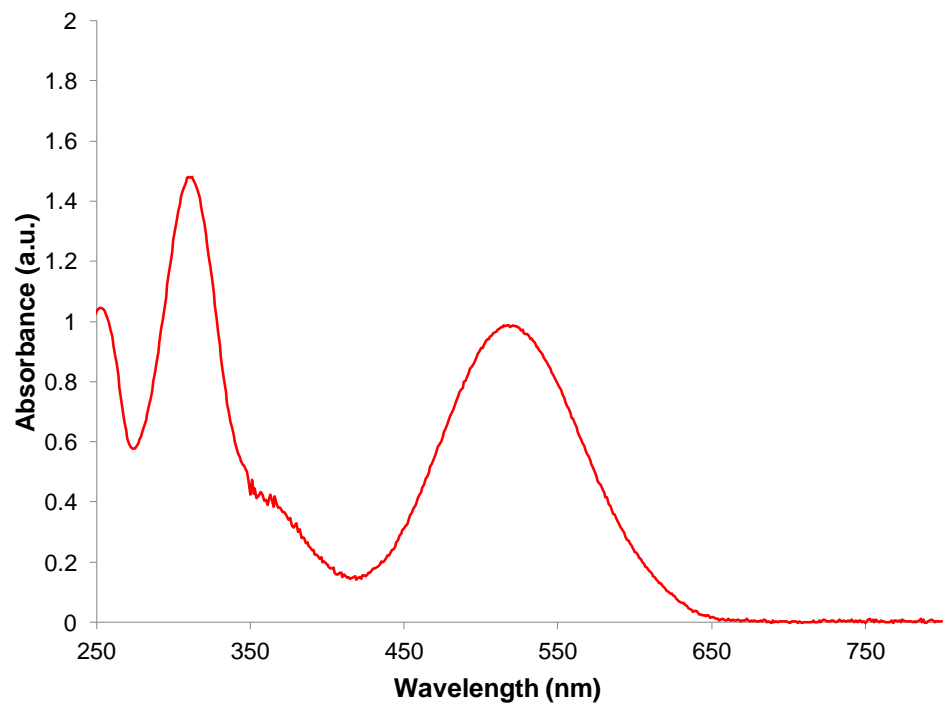

Fig. S16 UV-Vis absorption spectrum of $\mathrm{BF}_{2}$ formazanate polymer 12 recorded in $\mathrm{CH}_{2} \mathrm{Cl}_{2}$. 


\section{Cyclic Voltammetry Data}
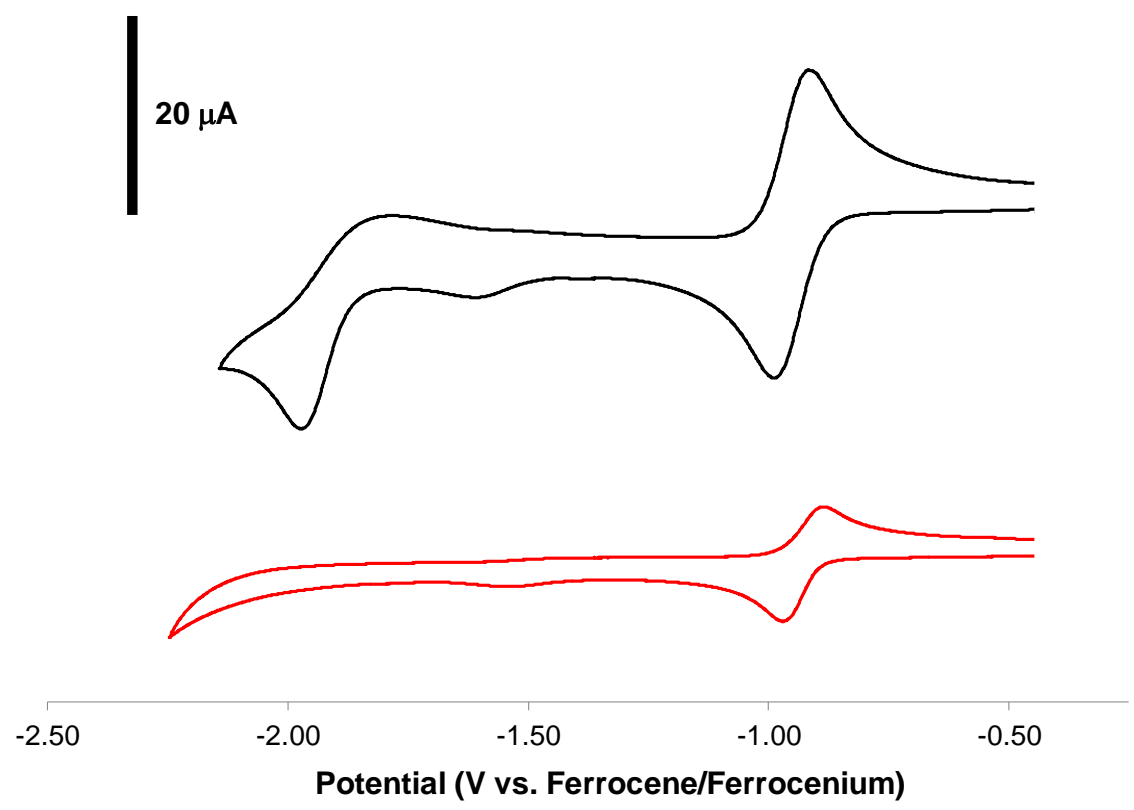

Fig. S17 Cyclic voltammograms for $\mathrm{BF}_{2}$ formazanate monomer 11 (black line) and polymer 12 (red line) recorded in dry, degassed THF containing $\sim 1 \mathrm{mM}$ analyte and 0.1 $\mathrm{M} n \mathrm{Bu}_{4} \mathrm{NPF}_{6}$ at a scan rate of $250 \mathrm{mV} \mathrm{s}^{-1}$.

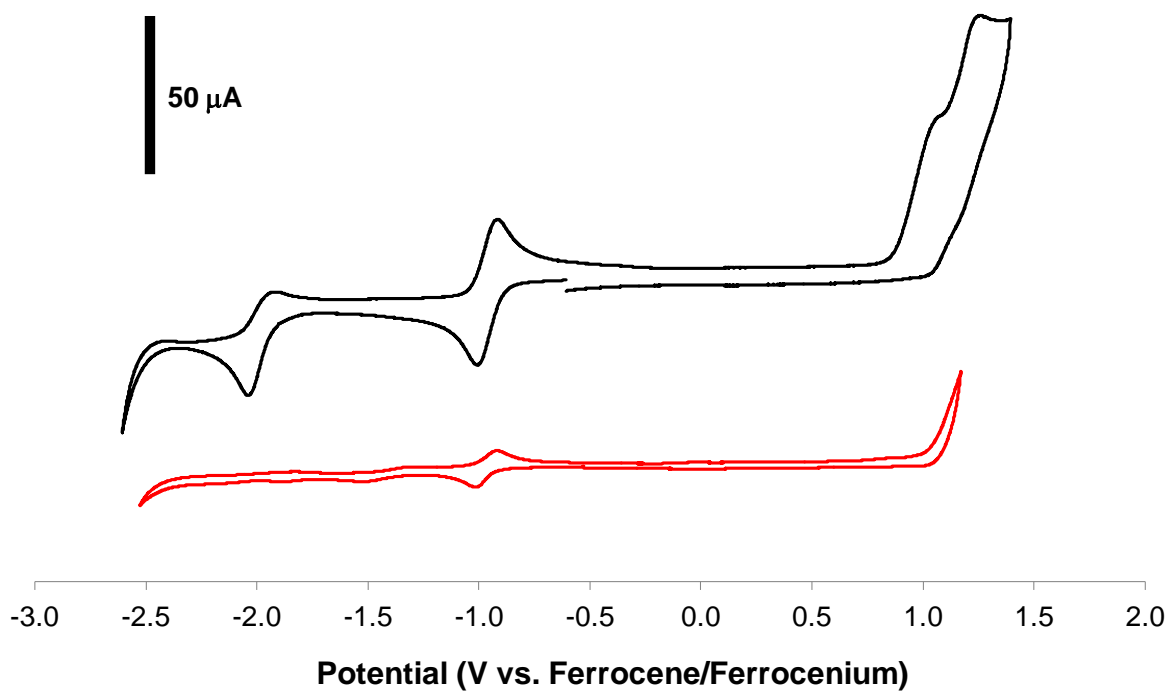

Fig. S18 Cyclic voltammograms for $\mathrm{BF}_{2}$ formazanate monomer 11 (black line) and polymer 12 (red line) recorded in dry, degassed $\mathrm{CH}_{2} \mathrm{Cl}_{2}$ containing $\sim 1 \mathrm{mM}$ analyte and $0.1 \mathrm{M} n \mathrm{Bu}_{4} \mathrm{NPF}_{6}$ at a scan rate of $250 \mathrm{mV} \mathrm{s}^{-1}$. 